\title{
Synthesis and Antimicrobial Activity of Chromone-linked 2-Pyridone Fused with 1,2,4-Triazoles, 1,2,4-Triazines and 1,2,4-Triazepines Ring Systems
}

\author{
Tarik El-Sayed Ali and Magdy Ahmed Ibrahim* \\ Department of Chemistry, Faculty of Education, Ain Shams University, Roxy 11711, Cairo, Egypt
}

Três novas séries de sistemas heterocíclicos nitrogênio fundidos como o 1,2,4-triazol[1,5- $a$ ] piridinas (5-7 e 9), pirido[1,2-b][1,2,4]triazinas (10, 11, 13 e 15), e também pirido[1,2-b] [1,2,4] triazepinas $(\mathbf{1 7}, \mathbf{1 8}, \mathbf{2 0}$ e 22) ligadas a um fragmento cromona foram sintetizadas a partir do intermediário-chave 1,6-diamino-(6-cloro-4-oxo-4H-chromen-3-il)-2-oxo-1,2-diidropiridina-3,5dicarbonitrila (4) com alguns reagentes eletrofílicos. As estruturas dos compostos inéditos foram estabelecidas por análise elementar e dados espectrais. Todos os produtos foram testados quanto à sua atividade antimicrobiana in vitro. Os compostos 7, 9 e 15 mostraram as maiores atividades quando comparadas às drogas de referência.

Three series of novel fused nitrogen heterocyclic systems such as 1,2,4-triazolo[1,5- $a$ ] pyridines (5-7 and 9), pyrido[1,2- $b][1,2,4]$ triazines $(\mathbf{1 0}, \mathbf{1 1}, \mathbf{1 3}$ and 15), and pyrido[ $[1,2-b][1,2,4]$ triazepines $(\mathbf{1 7}, \mathbf{1 8}, 20$ and 22) linked with a chromone moiety were synthesized from the key intermediate 1,6-diamino-(6-chloro-4-oxo-4H-chromen-3-yl)-2-oxo-1,2-dihydropyridine-3,5-dicarbonitrile (4) with some electrophilic reagents. The structures of the novel compounds were established by elemental analyses and spectral data. All the products were also screened in vitro for their antimicrobial activity. Compounds 7, 9 and $\mathbf{1 5}$ showed the highest activities when compared with the reference drugs.

Keywords: chromone, o-diamine, triazolopyridone, pyridotriazine, pyridotriazepine, antimicrobial activity

\section{Introduction}

The pharmacodynamic versatility of 4-oxo- $4 H$-chromene moiety has been documented not only in many of its synthetic derivatives but also in several naturally occurring flavones and khellins. ${ }^{1-3}$ These synthesized and isolated derivatives were found to have a wide range of biological properties including antiinflammatory, ${ }^{4}$ analgesic, ${ }^{5}$ antimicrobial, ${ }^{6-8}$ antitumor ${ }^{9}$ and anticancer. ${ }^{10}$ Pyridines are an important class of heterocycles due to their practical and synthetic applications. ${ }^{11}$ In particular, some 2-pyridone derivatives possess diverse bioactivities such as analgesic, ${ }^{12}$ antiinflammatory ${ }^{13}$ and anticancer. ${ }^{14}$ On the other hand, 1,2,4-triazoles, 1,2,4-triazines and 1,2,4-triazepines have been found to possess a wide spectrum of pharmacological, medicinal and biological activities. ${ }^{15-20}$ As part of our research work aiming to the synthesis of a variety of fused heterocyclic systems for biological evaluation, we report here efficient and convenient synthetic methods of different

\footnotetext{
*e-mail: magdy_ahmed1977@yahoo.com
}

biodynamic nitrogen heterocycles such as 1,2,4-triazoles, 1,2,4-triazines and 1,2,4-triazepines fused with 2-pyridone ring containing a chromone moiety.

\section{Results and Discussion}

1,6-Diamino-(6-chloro-4-oxo-4H-chromen-3-yl)2-oxo-1,2-dihydropyridine-3,5-dicarbonitrile (4) was prepared in good yield by refluxing alcoholic solution of [6-chloro-4-oxo-4H-chromen-3-yl)methylene] malononitrile (2) with cyanoacetohydrazide or $N^{\prime}$-[(6chloro-4-oxo-4H-chromen-3-yl)-2-cyanoacetohydrazide (3) with malononitrile in the presence of a catalytic amount of piperidine (Scheme 1). The IR spectrum of compound 4 showed characteristic absorption bands at 3401, 3308 $\left(2 \mathrm{NH}_{2}\right), 2259(2 \mathrm{C} \equiv \mathrm{N}), 1681\left(\mathrm{C}=\mathrm{O}_{\text {pyridone }}\right)$ and $1641 \mathrm{~cm}^{-1}$ $\left(\mathrm{C}=\mathrm{O}_{\text {pyrone }}\right)$. Also, the ${ }^{1} \mathrm{H}$ NMR spectrum of 4 exhibited two characteristic singlet signals at $\delta 4.61\left(\mathrm{~N}-\mathrm{NH}_{2}\right)$ and $10.78 \mathrm{ppm}\left(\mathrm{C}-\mathrm{NH}_{2}\right)$. These results indicated the difference in nucleophilicity between the two amino groups. Thus, it is expected that the hydrazide $\beta$-nitrogen $\left(\mathrm{N}-\mathrm{NH}_{2}\right)$ is 
<smiles>O=Cc1coc2ccc(Cl)cc2c1=O</smiles>
1<smiles>CCOCCNC(N)=O</smiles><smiles>N#CC(C#N)=Cc1coc2ccc(Cl)cc2c1=O</smiles>

2<smiles>N#Cc1c(-c2coc3ccc(Cl)cc3c2=O)c(C#N)c(=O)n(N)c1N</smiles>

Scheme 1. Synthetic pathways for the formation of compound 4 .

more nucleophilic and will react more rapidly with the electron deficient carbon than the second amino group $\left(\mathrm{C}-\mathrm{NH}_{2}\right)$. Product 4 was assumed to be formed via an initial addition of the active methylene of malononitrile to the hydrazone linkage in $\mathbf{3}$ to yield a Michael adduct $\mathbf{A}$. This adduct dissociates into 2-cyanoacetohydrazide and 2, which then further react in the way described earlier by El-Najar and co-workers ${ }^{21}$ to yield an intermediate tricyanobutyrohydrazide $\mathbf{B}$ that cyclizes to intermediates C then D. The intermediate $\mathbf{D}$ underwent dehydrogenation to afford the isolated product 4 (Scheme 2).
The 1,6-diamino groups are ready-made nucleophilic centers for the synthesis of fused nitrogen heterocyclic rings. ${ }^{22}$ Thus, compound $\mathbf{4}$ is a useful intermediate for the synthesis of new triazolopyridone, pyridotriazine and pyridotriazepine derivatives. Heterocyclization of compound 4 with ethyl formate and acetic anhydride afforded the triazolo[1,5- $a$ ]pyridine derivatives 5 and $\mathbf{6}$, respectively (Scheme 3 ). The IR and ${ }^{1} \mathrm{H}$ NMR spectra of the latter compounds confirmed the absence of the two $\mathrm{NH}_{2}$ groups. Furthermore, their ${ }^{1} \mathrm{H}$ NMR spectra showed characteristic singlet signal at $\delta 8.61 \mathrm{ppm}$ for $\mathrm{H}-3$ of
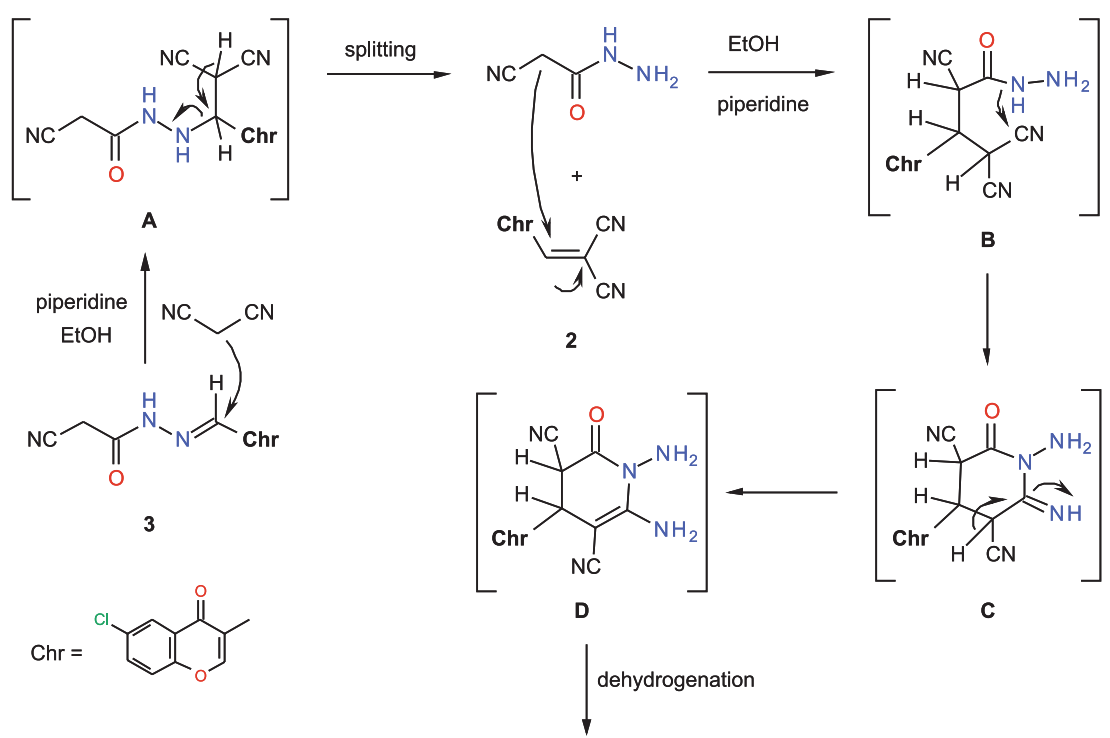<smiles>N#Cc1c(N)c(N)n(N)c(=O)c1C#N</smiles> 
triazole moiety in compound $\mathbf{5}$ and two singlet signals at $\delta 2.75$ and $2.91 \mathrm{ppm}$ corresponding to the two methyl groups in compound $\mathbf{6}$.

In continuation to our interest in the synthesis of chromone derivatives containing nitrogen heterocyclic systems, ${ }^{7,8,23}$ compound $\mathbf{4}$ was allowed to react with some chromone derivatives. Thus, cyclocondensation of 4 with 6-chloro-3-formylchromone (1) in DMF under reflux containing few drops of piperidine afforded the 1,2,3,5-tetrahydro[1,2,4] triazolo[1,5-a]pyridine derivative 7. Oxidation of the latter compound by ferric chloride in boiling DMSO yielded 2,7-bis(6-chloro-4-oxo-4Hchromen-3-yl)-5-oxo-1,5-dihydro-1,2,4-triazolo [1,5-a] pyridine-6,8-dicarbonitrile (9). Compound 9 was also obtained by refluxing 4 with 6-chloro-chromone-3carboxylic acid (8) in phosphorus oxychloride (Scheme 3). The analytical and spectral data of $\mathbf{7}$ and $\mathbf{9}$ are in agreement with the proposed structures. Thus, the ${ }^{1} \mathrm{H}$ NMR spectrum of 7 showed a triplet signal at $\delta 6.99 \mathrm{ppm}$ corresponding to $\mathrm{N}-\mathrm{CH}-\mathrm{N}$ hydrogen of triazole moiety and a doublet signal at $\delta 10.51 \mathrm{ppm}$ due to $\mathrm{N}^{2}-\mathrm{H}$ hydrogen of the triazole moiety. These two hydrogens were absent in the ${ }^{1} \mathrm{H}$ NMR spectrum of compound 9 that confirmed the oxidation process of its dihydroanalogue 7 .

Next, we allowed compound 4 to react with 1,2-dielectrophilic reagents to develop a facile and convenient route to polysubstituted pyrido[1,2-b][1,2,4] triazine derivatives with an expected wide spectra of biological activities. ${ }^{24}$ Thus, cyclocondensation of $\mathbf{4}$ with ethyl 2-chloro-3-oxobutanoate in DMF containing a catalytic amount of piperidine under reflux produced the pyrido[1,2- $b][1,2,4]$ triazine-2-carboxylate derivative 10, which was transformed to the pyrido[1,2-b][1,2,4] triazino[4,5- $d][1,2,4]$ triazine derivative $\mathbf{1 1}$ upon fusion with benzoic acid hydrazide (Scheme 4). The IR spectrum of compound $\mathbf{1 1}$ exhibited characteristic absorption bands at 3335, $3197(\mathrm{OH}, \mathrm{NH}), 2265,2221(2 \mathrm{C} \equiv \mathrm{N})$, $1672\left(\mathrm{C}=\mathrm{O}_{\text {pyridone }}\right)$ and $1633 \mathrm{~cm}^{-1}\left(\mathrm{C}=\mathrm{O}_{\text {pyrone }}\right)$. Also, its ${ }^{1} \mathrm{H}$ NMR spectrum displayed signals at $\delta 1.91,10.53$ and $13.27 \mathrm{ppm}$ corresponding to methyl, $\mathrm{NH}$ and $\mathrm{OH}$ hydrogens, respectively. The absence of the triplet and quartet signals corresponding to the ethoxycarbonyl hydrogens of compound $\mathbf{1 0}$ supported the formation of compound $\mathbf{1 1}$.

On the other hand, the interaction of 4 with 2,3-dichloroquinoxaline (12) and 3-chloro-7,8-diphenyl4H-1,2,4-triazino[4,3-b][1,2,4]triazine (14) in pyridine led to the formation of the corresponding quinoxalino[2,3-e] pyrido[1,2- $b][1,2,4]$ triazine $\mathbf{1 3}$ and pyrido[1,2-b][1,2,4] triazino[3', $\left.2^{\prime}: 3,4\right]$ triazino[5,6-e][1,2,4]triazine $\mathbf{1 5}$, respectively (Scheme 4). The ${ }^{1} \mathrm{H}$ NMR spectrum of $\mathbf{1 3}$ showed four broad signals at $\delta 10.72,11.28,11.94$ and $12.21 \mathrm{ppm}$ assignable to four $\mathrm{NH}$ hydrogens which confirmed that the product $\mathbf{1 3}$ exists in two tautomeric forms 13A and 13B due to amino-imino tautomerism.

The study was extended to investigate the behavior of 1,6-diaminopyridone derivative 4 towards some 1,3-dielectrophilic reagents which represents a new, simple and efficient synthetic route to prepare pyrido[1,2- $b]$ $[1,2,4]$ triazepine derivatives. Therefore, refluxing 4 with acetylacetone and arylidene malononitrile $\mathbf{1 6}$ in DMF containing few drops of piperidine as a basic catalyst furnished the pyrido[1,2- $b][1,2,4]$ triazepine derivatives $\mathbf{1 7}$ and 18, respectively (Scheme 5). The ${ }^{1} \mathrm{H}$ NMR spectrum of $\mathbf{1 7}$ showed a singlet signal at $\delta 4.63 \mathrm{ppm}$ due to $\mathrm{CH}_{2}$ hydrogens while compound $\mathbf{1 8}$ displayed broad signals at

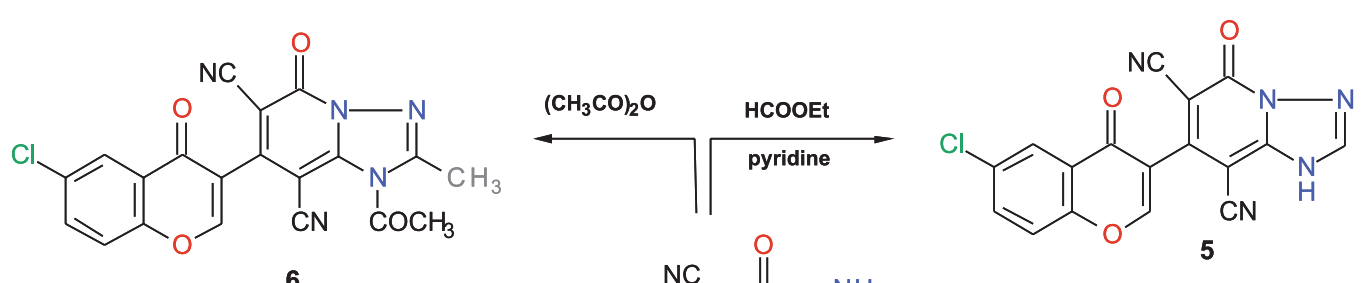

6<smiles>O=Cc1coc2ccc(Cl)cc2c1=O</smiles>

1<smiles>N#Cc1c(-c2coc3ccc(Cl)cc3c2=O)c(C#N)c(=O)n2c1NC(c1coc3ccc(Cl)cc3c1=O)N2</smiles><smiles>C=C1C(C#N)=C(c2coc3ccc(Cl)cc3c2=O)C(C#N)=C(N)N1N</smiles>

4<smiles>O=C(O)c1coc2ccc(Cl)cc2c1=O</smiles><smiles>COCCOc1ccc2occ(-c3c(C#N)c(=O)n4nc(-c5coc6ccc(Cl)cc6c5=O)[nH]c4c3C#N)c(=O)c2c1</smiles>

Scheme 3. Synthetic pathway for the formation of 1,2,4-triazolo[1,5-a]pyridines. 
$\delta 8.89$ and $10.67 \mathrm{ppm}$ assigned to $\mathrm{NH}_{2}$ and $\mathrm{NH}$ hydrogens, respectively.

Furthermore, we also investigated the reactivity of $\mathbf{4}$ towards enaminone and ketene $N, S$-acetal. Thus, reaction of 4 with 4-(dimethylamino)but-3-en-2-one (19) in glacial acetic acid afforded the 5,7-dihydropyrido[1,2-b] $[1,2,4]$ triazepine derivative 20 (Scheme 5). The structure of the latter product was confirmed from its elemental

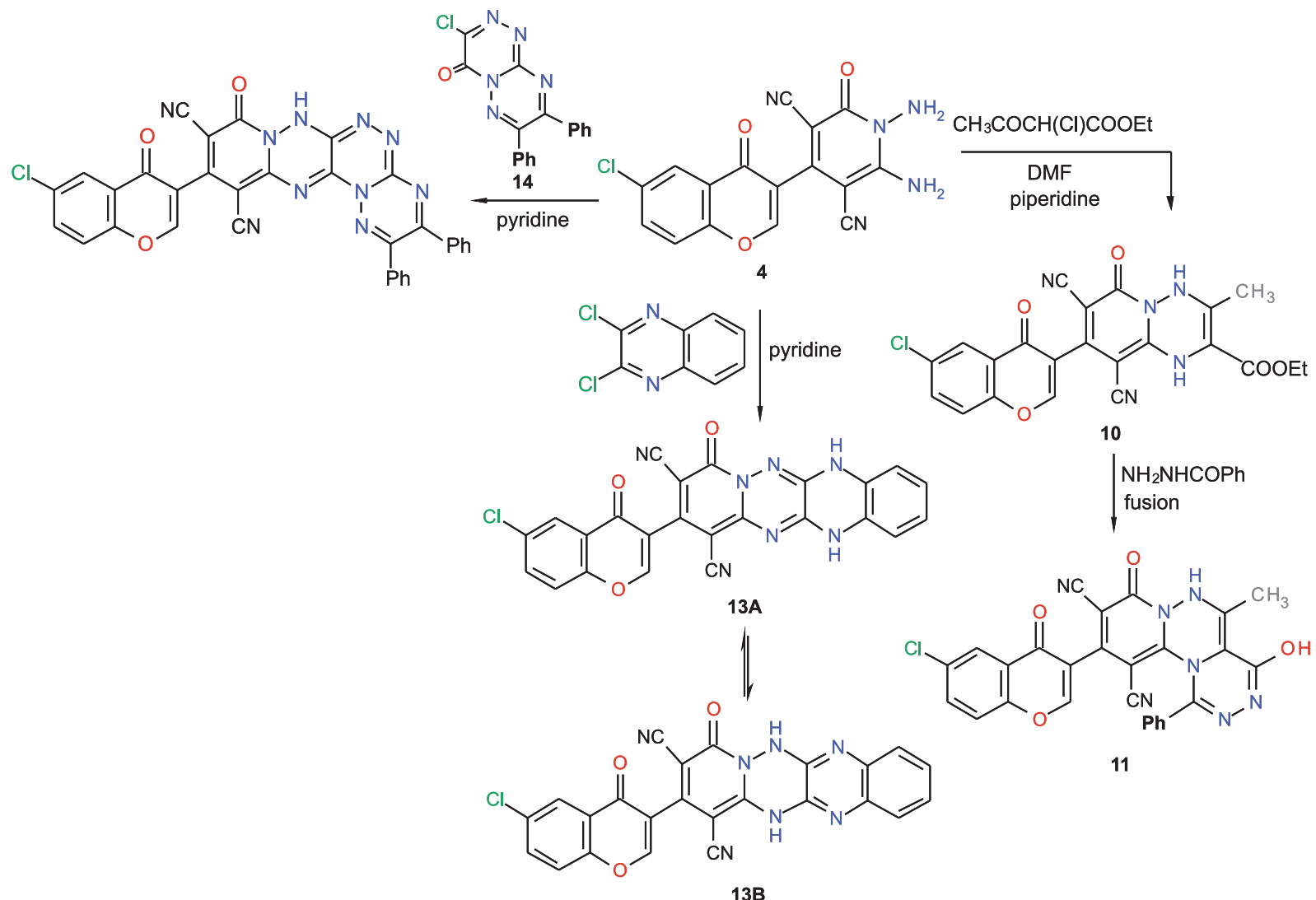

Scheme 4. Synthetic pathway for the formation of pyrido[1,2-b][1,2,4]triazines.<smiles></smiles>

20<smiles></smiles><smiles>N#Cc1c(-c2coc3ccc(Cl)cc3c2=O)c(C#N)c(=O)n(N)c1N</smiles><smiles>N#Cc1c(-c2coc3ccc(Cl)cc3c2=O)c(C#N)c(=O)n2c1N=C(N)C(C(=O)Nc1ccccc1)=C(Nc1ccccc1)N2</smiles>

22

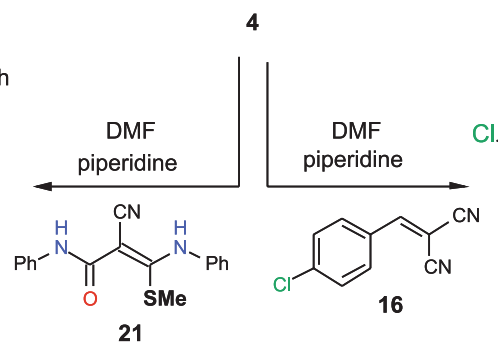<smiles></smiles>

18 $\mathrm{Ar}=4-\mathrm{ClC}_{6} \mathrm{H}_{4}$

Scheme 5. Synthetic pathway for the formation of pyrido[1,2- $b][1,2,4]$ triazepines. 
analysis which agreed well with the molecular formula $\mathrm{C}_{20} \mathrm{H}_{10} \mathrm{ClN}_{5} \mathrm{O}_{3}$. Also, its ${ }^{1} \mathrm{H}$ NMR spectrum showed a singlet signal at $\delta 2.34 \mathrm{ppm}$ corresponding to the methyl hydrogens, besides a doublet signal at $\delta 7.94 \mathrm{ppm}$ assigned to $\mathrm{C}_{7}-\mathrm{H}$ hydrogen of triazepine ring. The formation of compound $\mathbf{2 0}$ was assumed to take place via an initial Michael addition of the hydrazide $\beta$-nitrogen $\left(\mathrm{N}-\mathrm{NH}_{2}\right)$ group in $\mathbf{4}$ to the activated double bond in enaminone followed by cyclization via loss of both dimethylamine and water molecules. ${ }^{24}$

Finally, treatment of $\mathbf{4}$ with ketene $N, S$-acetal derivative 21 in DMF under reflux containing few drops of piperidine produced 2-amino-9-(6-chloro-4-oxo-4H-chromen-3yl)-8,10-dicyano- $N$-phenyl-4-(phenylamino)-7-oxo-5,7dihydropyrido[1,2-b][1,2,4]triazepine-3-carboxamide (22) (Scheme 5). The formation of $\mathbf{2 2}$ was assumed to take place via nucleophilic attack of $\left(\mathrm{N}-\mathrm{NH}_{2}\right)$ on compound 21 to remove methanethiol followed by cycloaddition of the second amino group $\left(\mathrm{C}-\mathrm{NH}_{2}\right)$ on the nitrile group. The IR spectrum of $\mathbf{2 2}$ showed absorption bands for $\mathrm{NH}_{2}, \mathrm{NH}$ and $\mathrm{C}=\mathrm{O}_{\text {amide }}$ groups at $3375-3325,3152$ and $1648 \mathrm{~cm}^{-1}$, respectively, while its ${ }^{1} \mathrm{H}$ NMR spectrum showed signals at $\delta 8.08,9.91,10.63$ and 11.08 ppm assigned to the $\mathrm{NH}_{2}$ and three $\mathrm{NH}$ hydrogens, respectively.

\section{Antimicrobial activity}

The standardized disc agar diffusion method ${ }^{25}$ was followed to determine the activity of the synthesized compounds against the sensitive organisms Staphylococcus aureus (ATCC 25923) and Streptococcus pyogenes (ATCC 19615) as Gram positive bacteria, Pseudomonas fluorescens (S 97) and Pseudomonas phaseolicola (GSPB 2828) as Gram negative bacteria and two species of fungi, namely Fusarium oxysporum and Aspergillus fumigatus. The antibiotic chloramphenicol was used as reference in the case of Gram negative bacteria, while cephalothin was used in the case of Gram positive bacteria and cycloheximide was used as antifungal reference.

The compounds were dissolved in DMF which has no inhibition activity to get concentration of $2 \mathrm{mg} \mathrm{mL}^{-1}$. The test was performed on medium potato dextrose agars (PDA) which contain infusion of $200 \mathrm{~g}$ potatoes, $6 \mathrm{~g}$ dextrose and $15 \mathrm{~g}$ agar. ${ }^{26}$ Uniform size filter paper disks (3 disks per compound) were impregnated with equal volume $(10 \mu \mathrm{L})$ from the specific concentration of dissolved tested compounds and carefully placed on inoculated agar surface. After incubation for $36 \mathrm{~h}$ at $27^{\circ} \mathrm{C}$ in the case of bacteria and for $48 \mathrm{~h}$ at $24^{\circ} \mathrm{C}$ in the case

Table 1. The antimicrobial activity of compounds 4-7, 9-11, 13, 15, 17, 18, 20 and 22

\begin{tabular}{|c|c|c|c|c|c|c|}
\hline \multirow{3}{*}{ Compd. No. } & \multicolumn{6}{|c|}{ Diameter of the inhibition zone in $\mathrm{mm}^{a, b}$ (activity index) ${ }^{c}$} \\
\hline & \multicolumn{2}{|c|}{ Gram positive bacteria } & \multicolumn{2}{|c|}{ Gram negative bacteria } & \multicolumn{2}{|c|}{ Fungal strains } \\
\hline & S. aureus & S. pyogenes & P. phaseolicola & P. fluorescens & F. oxysporum & A. fumigatus \\
\hline 4 & $4(0.14)$ & $3(0.10)$ & $8(0.32)$ & $9(0.30)$ & $6(0.21)$ & $7(0.22)$ \\
\hline 5 & $12(0.43)$ & $13(0.43)$ & $14(0.56)$ & $22(0.73)$ & $14(0.50)$ & $15(0.48)$ \\
\hline 6 & $18(0.64)$ & $16(0.53)$ & $16(0.64)$ & $13(0.43)$ & $10(0.36)$ & $13(0.43)$ \\
\hline 7 & $23(0.82)$ & $21(0.70)$ & $17(0.68)$ & $21(0.70)$ & $16(0.57)$ & $21(0.68)$ \\
\hline 9 & $25(0.89)$ & $26(0.87)$ & $15(0.60)$ & $18(0.60)$ & $20(0.71)$ & $19(0.61)$ \\
\hline 10 & $7(0.25)$ & $6(0.20)$ & $4(0.16)$ & $10(0.33)$ & $8(0.28)$ & $5(0.16)$ \\
\hline 11 & $11(0.39)$ & $13(0.43)$ & $16(0.64)$ & $10(0.33)$ & $10(0.36)$ & $12(0.39)$ \\
\hline 13 & $10(0.36)$ & $13(0.43)$ & $12(0.48)$ & $17(0.57)$ & $8(0.28)$ & $6(0.19)$ \\
\hline 15 & $24(0.86)$ & $23(0.77)$ & $18(0.72)$ & $22(0.73)$ & $21(0.75)$ & $27(0.87)$ \\
\hline 17 & $5(0.18)$ & $7(0.23)$ & $7(0.28)$ & $10(0.33)$ & $5(0.18)$ & $8(0.25)$ \\
\hline 18 & $6(0.21)$ & $6(0.20)$ & $7(0.28)$ & $12(0.40)$ & $20(0.71)$ & $14(0.45)$ \\
\hline 20 & $12(0.43)$ & $14(0.47)$ & $15(0.60)$ & $22(0.73)$ & $14(0.50)$ & $15(0.48)$ \\
\hline 22 & $4(0.14)$ & $7(0.23)$ & $7(0.28)$ & $10(0.33)$ & $8(0.28)$ & $4(0.13)$ \\
\hline chloramphenicol & - & - & 25 & 30 & - & - \\
\hline cephalothin & 28 & 30 & - & - & - & - \\
\hline cycloheximide & - & - & - & - & 28 & 31 \\
\hline
\end{tabular}

${ }^{a}$ Calculated from 3 values; ${ }^{b}$ Identified depending on morphological and microscopical characteristics: Low activity $=$ mean of zone diameter $\leq 0.33$ of mean zone diameter of reference. Moderate activity = mean of zone diameter $>0.33 \leq 0.66$ of mean zone diameter of the reference compound. High activity $=$ mean of zone diameter $\geq 0.67$ of mean zone diameter of the reference compound; ${ }^{c}$ Activity index: inhibition zone of the sample /inhibition zone of the reference compound. 
of fungi, inhibition of the organisms was measured and used to calculate mean of inhibition zones. Activity index of all the synthesized compounds was also calculated against the corresponding standard drug (Table 1). The products showed various activities against all species of microorganisms which suggest that the variations in the structures affect on the growth of the microorganisms. Thus, we can conclude from these results: $i$ ) The prepared compounds showed a moderate to high antimicrobial activity towards all species of bacteria and fungi (Table 1); ii) It is known that compounds having oxygen heterocycles and active hydrogen at nitrogen groups $(\mathrm{NH})$ can be preferable in the design of good bioregulators with desirable prompt biological activity. Also, the chromon-3-yl residue can simultaneously increase the activity and decrease the toxicity of nitrogen heterocycles. ${ }^{27}$ Thus, the building up of compounds containing more nitrogen heterocycles on the 1,6-diamino-(6-chloro-4-oxo$4 H$-chromen-3-yl)-2-oxo-1,2-dihydropyridine-3,5dicarbonitrile (4) may enhance the biological activities in most of the products in comparison with compound 4; iii) Compounds which have 1,2,4-triazole ring fused with 2-pyridone showed greater activity than that of 1,2,4-triazine and 1,2,4-triazepine; iv) Compounds 7 and 9 showed the highest antimicrobial activity. This high effect may due to the presence of two chromone moieties besides the triazolopyridone moiety. Also, compound $\mathbf{1 5}$ has the same effect which may be attributed to the presence of polyfused bioactive 1,2,4-triazine systems. ${ }^{28}$ Therefore, these compounds may be considered promising for the development of new antimicrobial agents.

\section{Conclusion}

We have successfully synthesized three series of novel fused nitrogen heterocyclic systems such as 1,2,4-triazolo[1,5-a]pyridines, pyrido[1,2- $b][1,2,4]$ triazines and pyrido[1,2- $b][1,2,4]$ triazepines linked with a chromone moiety. The antimicrobial activities of the prepared compounds showed that polyheterocyclic systems 7, 9 and $\mathbf{1 5}$ have good inhibitory effects when compared with the starting material.

\section{Experimental}

Melting points were determined on a digital Stuart SMP3 apparatus. Infrared spectra were measured on PerkinElmer 293 spectrophotometer using $\mathrm{KBr}$ disks. ${ }^{1} \mathrm{H}$ NMR spectra were measured on Gemini-200 spectrometer $\left(200 \mathrm{MHz}\right.$ ), using DMSO- $d_{\sigma}$ as solvent and TMS ( $\delta$ in $\mathrm{ppm})$ as an internal standard. Elemental microanalyses were performed at Microanalysis Unit in National Research Center. Evaluation of antimicrobial activities was carried out in the Faculty of Agriculture, Al-Azhar University for Girls, Nasr-City, Cairo, Egypt. 6-Chloro-3formylchromone (1), ${ }^{29}[$ (6-chloro-4-oxo-4H-chromen-3-yl) methylene] malononitrile (2), ${ }^{30} \mathrm{~N}^{\prime}$-[(6-chloro-4-oxo- $4 \mathrm{H}$ chromen-3-yl)methylene]-2-cyanoacetohydrazide (3), ${ }^{31}$ 6-chloro-chromone-3-carboxylic acid (8), ${ }^{32} 3$-chloro7,8-diphenyl-4H-[1,2,4]triazino[4,3-b][1,2,4] triazin-4one (14) ${ }^{33}$ and 2-cyano-3-(methylsulfanyl)- $N$-phenyl-3(phenylamino)prop-2-enamide $(\mathbf{2 1})^{34}$ were prepared by published methods in literature.

1,6-Diamino-(6-chloro-4-oxo-4H-chromen-3-yl)-2-oxo1,2-dihydropyridine-3,5-dicarbonitrile (4)

\section{Method A}

A mixture of [(6-chloro-4-oxo-4H-chromen-3-yl) methylene]malononitrile (2) (1280 mg, $5 \mathrm{mmol})$ and cyanoacetohydrazide $(500 \mathrm{mg}, 5 \mathrm{mmol})$, in absolute ethanol $(30 \mathrm{~mL})$ containing few drops of piperidine, was refluxed for $3 \mathrm{~h}$. After cooling, the formed solid was filtered and recrystallized from DMF to afford $\mathbf{4}$ as beige crystals, yield $74 \%, \mathrm{mp} 288-289^{\circ} \mathrm{C}$.

\section{Method B}

A mixture of $N^{\prime}$-[(6-chloro-4-oxo- $4 H$-chromen-3-yl) methylene]-2-cyanoaceto-hydrazide (3) (1450 mg, $5 \mathrm{mmol}$ ) and malononitrile ( $330 \mathrm{mg}, 5 \mathrm{mmol}$ ), in absolute ethanol $(30 \mathrm{~mL})$ containing few drops of piperidine, was refluxed for $3 \mathrm{~h}$. After cooling, the formed solid was filtered and crystallized from DMF to afford $\mathbf{4}$ as beige crystals, yield $77 \%$, mp 288-290 ${ }^{\circ} \mathrm{C}$. IR (KBr) $v_{\max } / \mathrm{cm}^{-1}: 3401,3308$ $\left(2 \mathrm{NH}_{2}\right), 3058\left(\mathrm{C}-\mathrm{H}_{\text {arom }}\right), 2259(2 \mathrm{C} \equiv \mathrm{N}), 1681\left(\mathrm{C}=\mathrm{O}_{\text {pyridone }}\right)$, $1641\left(\mathrm{C}=\mathrm{O}_{\text {pyrone }}\right), 1468\left(\mathrm{NH}_{2}\right.$ def.). ${ }^{1} \mathrm{H}$ NMR (DMSO-d $)$ $\delta 4.61$ (s, 2H, N-NH $), 7.13$ (d, 1H, J 8 Hz, H-8), 7.54 (d, $1 \mathrm{H}, J 8 \mathrm{~Hz}, \mathrm{H}-7), 8.53$ (s, 1H, H-5), 9.48 (s, 1H, H-2), 10.78 (s, $2 \mathrm{H}, \mathrm{C}-\mathrm{NH}_{2}$ ). Anal. Calc. for $\mathrm{C}_{16} \mathrm{H}_{8} \mathrm{ClN}_{5} \mathrm{O}_{3}$ (353.71): C, 54.33; H, 2.28; N, 19.80; Cl, 10.02. Found: C, 54.01; $\mathrm{H}, 2.02 ; \mathrm{N}, 19.54 ; \mathrm{Cl}, 9.69 \%$.

7-(6-Chloro-4-oxo-4H-chromen-3-yl)-5-oxo-1,5dihydro[1,2,4]triazolo[1,5-a]pyridine-6,8-dicarbonitrile (5)

A mixture of compound 4 (1710 mg, $5 \mathrm{mmol}$ ) and ethyl formate $(370 \mathrm{mg}, 5 \mathrm{mmol})$ in dry pyridine $(30 \mathrm{~mL})$ was refluxed for $10 \mathrm{~h}$. After cooling the reaction mixture was poured onto ice and neutralized with concentrated $\mathrm{HCl}$. The formed solid was filtered, washed several times with water and crystallized from $\mathrm{DMF} / \mathrm{H}_{2} \mathrm{O}$ to give $\mathbf{5}$ as brown crystals, yield $68 \%$, mp $274-276{ }^{\circ} \mathrm{C}$. IR $(\mathrm{KBr}) \mathrm{v}_{\max } / \mathrm{cm}^{-1}$. 
$3261(\mathrm{NH}), 3037\left(\mathrm{C}-\mathrm{H}_{\text {arom }}\right), 2261(2 \mathrm{C} \equiv \mathrm{N}), 1683$ $\left(\mathrm{C}=\mathrm{O}_{\text {pyridone }}\right), 1638\left(\mathrm{C}=\mathrm{O}_{\text {pyrone }}\right) .{ }^{1} \mathrm{H}$ NMR $\left(\right.$ DMSO- $\left.d_{6}\right) \delta 7.10$ (d, 1H, J $8.2 \mathrm{~Hz}, \mathrm{H}-8), 7.55$ (d, 1H, J $8.2 \mathrm{~Hz}, \mathrm{H}-7), 8.53$ (s, 1H, H-5), 8.61 (s, 1H, H-3 $3_{\text {triazole }}$ ), 9.50 (s, 1H, H-2), 10.74 (br, $1 \mathrm{H}, \mathrm{NH})$. Anal. Calc. for $\mathrm{C}_{17} \mathrm{H}_{6} \mathrm{ClN}_{5} \mathrm{O}_{3}(363.71)$ : C, 56.14; H, 1.66; N, 19.26; Cl, 9.75. Found: C, 55.78; $\mathrm{H}, 1.52 ; \mathrm{N}, 18.89 ; \mathrm{Cl}, 9.41 \%$.

1-Acetyl-7-(6-chloro-4-oxo-4H-chromen-3-yl)-2-methyl5-oxo-1,5-dihydro-1,2,4-triazolo [1,5-a]pyridine-6,8dicarbonitrile (6)

A solution of compound 4 (1710 mg, $5 \mathrm{mmol})$ in acetic anhydride $(10 \mathrm{~mL})$ was refluxed for $6 \mathrm{~h}$. The excess solvent was removed under vacuum to give a solid which was crystallized from ethanol to afford $\mathbf{6}$ as brown crystals, yield $47 \%$, mp 297-299 ${ }^{\circ} \mathrm{C}$. IR ( KBr) $v_{\max } / \mathrm{cm}^{-1}: 3073\left(\mathrm{C}-\mathrm{H}_{\text {arom }}\right)$, $2926\left(\mathrm{C}-\mathrm{H}_{\text {aliph }}\right), 2239(2 \mathrm{C} \equiv \mathrm{N}), 1722\left(\mathrm{C}=\mathrm{O}_{\text {acetyl }}\right), 1675$ $\left(\mathrm{C}=\mathrm{O}_{\text {pyridone }}\right), 1622\left(\mathrm{C}=\mathrm{O}_{\text {pyrone }}\right) .{ }^{1} \mathrm{H}$ NMR (DMSO- $\left.d_{6}\right) \delta 2.75$ (s, $\left.3 \mathrm{H}, \mathrm{CH}_{3}\right), 2.91\left(\mathrm{~s}, 3 \mathrm{H}, \mathrm{CH}_{3}\right), 7.07-7.97(\mathrm{~m}, 2 \mathrm{H}, \mathrm{H}-8$ and H-7), 8.66 (s, 1H, H-5), 9.51 (s, 1H, H-2). Anal. Calc. for $\mathrm{C}_{20} \mathrm{H}_{10} \mathrm{ClN}_{5} \mathrm{O}_{4}$ (419.77): C, 57.22; H, 2.40; N, 16.68; $\mathrm{Cl}, 8.44$. Found: C, 56.94; H, 2.12; N, 16.32; Cl, 8.07\%.

\section{2,7-Bis(6-chloro-4-oxo-4H-chromen-3-yl)-5-oxo-} 1,2,3,5-tetrahydro[1,2,4]triazolo[1,5-a] pyridine-6,8dicarbonitrile (7)

A mixture of compound $4(1710 \mathrm{mg}, 5 \mathrm{mmol})$ and 6-chloro-3-formylchromone (1) (1040 mg, $5 \mathrm{mmol})$, in DMF (30 mL) containing few drops of piperidine, was refluxed for $5 \mathrm{~h}$. After cooling, the reaction mixture was poured onto ice. The formed solid was filtered and crystallized from DMF/ethanol to afford 7 as yellow crystals, yield 93\%, mp $>300{ }^{\circ} \mathrm{C}$. IR $(\mathrm{KBr}) \mathrm{v}_{\max } / \mathrm{cm}^{-1}$ : 3395, $3186(2 \mathrm{NH}), 3075\left(\mathrm{C}-\mathrm{H}_{\text {arom }}\right), 2928\left(\mathrm{C}-\mathrm{H}_{\text {aliph }}\right), 2263$ $(2 \mathrm{C} \equiv \mathrm{N}), 1680\left(\mathrm{C}=\mathrm{O}_{\text {pyridone }}\right), 1632\left(2 \mathrm{C}=\mathrm{O}_{\text {pyrone }}\right) .{ }^{1} \mathrm{H}$ NMR $\left(\mathrm{DMSO}-d_{6}\right) \delta 6.99\left(\mathrm{t}, 1 \mathrm{H}, \mathrm{N}-\mathrm{CH}-\mathrm{N}_{\text {triazole }}\right), 7.37-7.96(\mathrm{~m}$, 4H, H-8, H-8', H-7 and H-7'), 8.35 (s, 1H, H-5), 8.53 (s, 1H, H-5 ), 8.78 (s, 1H, H-2), 9.47 (s, 1H, H-2'), 10.51 (d, $1 \mathrm{H}, \mathrm{NH}), 12.72(\mathrm{br}, 1 \mathrm{H}, \mathrm{NH})$. Anal. Calc. for $\mathrm{C}_{26} \mathrm{H}_{11} \mathrm{Cl}_{2} \mathrm{~N}_{5} \mathrm{O}_{5}$ (544.30): C, 57.37; H, 2.04; N, 12.87; Cl, 13.02. Found: C, $57.02 ; \mathrm{H}, 1.75 ; \mathrm{N}, 12.58 ; \mathrm{Cl}, 12.71 \%$.

2,7-Bis(6-chloro-4-oxo-4H-chromen-3-yl)-5-oxo-1,5dihydro[1,2,4]triazolo[1,5-a] pyridine-6,8-dicarbonitrile (9)

\section{Method A}

A mixture of compound $4(1710 \mathrm{mg}, 5 \mathrm{mmol})$ and 6-chloro-chromone-3-carboxylic acid (8) $(1070 \mathrm{mg}$, $5 \mathrm{mmol})$ in $\mathrm{POCl}_{3}(10 \mathrm{~mL})$ was refluxed on water bath for $3 \mathrm{~h}$. After cooling, the reaction mixture was poured onto ice. The formed solid was filtered and crystallized from
DMF/ethanol to afford 9 as pale brown crystals, yield $88 \%$; $\mathrm{mp}>300^{\circ} \mathrm{C}$.

\section{Method B}

A mixture of compound 7 (1360 mg, $5 \mathrm{mmol}$ ) and ferric chloride $(2500 \mathrm{mg})$ in DMSO $(25 \mathrm{~mL})$ was refluxed for $4 \mathrm{~h}$. After cooling, the reaction mixture was poured onto $10 \%$ aqueous sodium carbonate solution $(75 \mathrm{~mL})$ and stirred for $1 \mathrm{~h}$ at room temperature. The formed solid was filtered and crystallized from DMF/ethanol to afford 9 as pale brown crystals, yield $82 \%, \mathrm{mp}>300^{\circ} \mathrm{C}$. IR $(\mathrm{KBr}) v_{\text {max }} / \mathrm{cm}^{-1}: 3402$ $(\mathrm{NH}), 3059\left(\mathrm{C}-\mathrm{H}_{\text {arom }}\right), 2258(2 \mathrm{C} \equiv \mathrm{N}), 1682\left(\mathrm{C}=\mathrm{O}_{\text {pyridone }}\right)$, $1641\left(2 \mathrm{C}=\mathrm{O}_{\text {pyrone }}\right), 1598(\mathrm{C}=\mathrm{N}) .{ }^{1} \mathrm{H}$ NMR (DMSO-d $\left.{ }_{6}\right)$ $\delta$ 7.07-7.79 (m, 4H, H-8, H-8', H-7 and H-7'), 8.35 (s, $1 \mathrm{H}$, H-5), 8.54 (s, 1H, H-5'), 8.68 (s, 1H, H-2), 9.51 (s, 1H, H-2'), 11.64 (br, $1 \mathrm{H}, \mathrm{NH}$ ). Anal. Calc. for $\mathrm{C}_{26} \mathrm{H}_{9} \mathrm{Cl}_{2} \mathrm{~N}_{5} \mathrm{O}_{5}$ (542.28): C, 57.59; H, 1.67; N, 12.91; Cl, 13.07. Found: C, $57.22 ; \mathrm{H}, 1.34 ; \mathrm{N}, 12.64 ; \mathrm{Cl}, 12.76 \%$.

Ethyl 8-(6-chloro-4-oxo-4H-chromen-3-yl)-7,9-dicyano3-methyl-6-oxo-1,6-dihydro-4H-pyrido[1,2-b][1,2,4] triazine-2-carboxylate (10)

A mixture of compound $4(1710 \mathrm{mg}, 5 \mathrm{mmol})$ and ethyl 2-chloro-3-oxobutanoate $(820 \mathrm{mg}, 5 \mathrm{mmol})$, in DMF $(30 \mathrm{~mL})$ containing few drops of piperidine, was refluxed for $8 \mathrm{~h}$. After cooling, the reaction mixture was onto icewater. The formed solid was filtered and crystallized from $\mathrm{AcOH} / \mathrm{H}_{2} \mathrm{O}$ to afford $\mathbf{1 0}$ as brown crystals, yield $69 \%, \mathrm{mp}$ $188-1900^{\circ} \mathrm{C}$. IR (KBr) $v_{\max } / \mathrm{cm}^{-1}: 3394,3199(2 \mathrm{NH}), 3044$ $\left(\mathrm{C}-\mathrm{H}_{\text {arom }}\right), 2978,2925\left(\mathrm{C}-\mathrm{H}_{\text {aliph }}\right), 2260,2198(2 \mathrm{C} \equiv \mathrm{N})$, $1734\left(\mathrm{C}=\mathrm{O}_{\text {ester }}\right), 1683\left(\mathrm{C}=\mathrm{O}_{\text {pyridone }}\right), 1635\left(\mathrm{C}=\mathrm{O}_{\text {pyrone }}\right), 1103$ $(\mathrm{C}-\mathrm{O}-\mathrm{C}) .{ }^{1} \mathrm{H}$ NMR (DMSO-d $\left.d_{6}\right) \delta 1.24(\mathrm{t}, 3 \mathrm{H}, J 7.2 \mathrm{~Hz}$, $\left.\mathrm{OCH}_{2} \mathrm{CH}_{3}\right), 2.23\left(\mathrm{~s}, 3 \mathrm{H}, \mathrm{CH}_{3}\right), 3.77$ (br, $2 \mathrm{H}, \mathrm{OCH}_{2} \mathrm{CH}_{3}$ ), 7.03-7.93 (m, 2H, H-8 and H-7), 8.53 (s, 1H, H-5), 9.51 (s, 1H, H-2), $10.64(\mathrm{~s}, 1 \mathrm{H}, \mathrm{NH}), 11.02(\mathrm{br}, 1 \mathrm{H}, \mathrm{NH})$. Anal. Calc. for $\mathrm{C}_{22} \mathrm{H}_{14} \mathrm{ClN}_{5} \mathrm{O}_{5}$ (463.83): C, 56.97; H, 3.04; $\mathrm{N}, 15.10 ; \mathrm{Cl}, 7.64$. Found: C, 56.69; H, 2.79; N, 14.78; $\mathrm{Cl}, 7.28 \%$.

1-Phenyl-10-(6-chloro-4-oxo-4H-chromen-3-yl)-4hydroxy-5-methyl-8-oxo-6H,8H-pyrido [1,2-b][1,2,4] triazino[4,5-d][1,2,4]triazine-9,11-dicarbonitrile (11)

A mixture of compound $\mathbf{1 0}(2310 \mathrm{mg}, 5 \mathrm{mmol})$ and benzoic acid hydrazide $(680 \mathrm{mg}, 5 \mathrm{mmol})$, containing few drops of triethylamine, was fused for $15 \mathrm{~min}$ at $190-200^{\circ} \mathrm{C}$. The reaction mixture was cooled at room temperature and treated with ethanol $(5 \mathrm{~mL})$. The formed solid was filtered and crystallized from ethanol to afford $\mathbf{1 1}$ as brown crystals, yield $44 \%$, mp 262-264 ${ }^{\circ} \mathrm{C}$. IR (KBr) $\nu_{\max } / \mathrm{cm}^{-1}: 3335$ (br, $\mathrm{OH}), 3197(\mathrm{NH}), 3050\left(\mathrm{C}-\mathrm{H}_{\text {arom }}\right), 2930\left(\mathrm{C}-\mathrm{H}_{\text {aliph }}\right), 2265$, $2221(2 \mathrm{C} \equiv \mathrm{N}), 1672\left(\mathrm{C}=\mathrm{O}_{\text {pyridone }}\right), 1633\left(\mathrm{C}=\mathrm{O}_{\text {pyrone }}\right), 1601$ 
$(\mathrm{C}=\mathrm{N}) .{ }^{1} \mathrm{H}$ NMR $\left(\mathrm{DMSO}-\mathrm{d}_{6}\right) \delta 1.91\left(\mathrm{br}, 3 \mathrm{H}, \mathrm{CH}_{3}\right), 7.05-7.95$ (m, 7H, H-8, H-7 and Ph-H), 8.52 (s, 1H, H-5), 9.50 (s, 1H, $\mathrm{H}-2$ ), 10.53 (s, 1H, NH), 13.27 (br, 1H, OH). Anal. Calc. for $\mathrm{C}_{27} \mathrm{H}_{14} \mathrm{ClN}_{7} \mathrm{O}_{4}(535.89)$ : C, 60.51; H, 2.63; N, 18.30; $\mathrm{Cl}, 6.61$. Found: $\mathrm{C}, 60.23 ; \mathrm{H}, 2.41 ; \mathrm{N}, 17.98 ; \mathrm{Cl}, 6.29 \%$.

11 -(6-Chloro-4-oxo-4H-chromen-3-yl)-9-oxo-9,13dihydro-7H-quinoxalino[2,3-e]pyrido [1,2-b][1,2,4] triazine-10,12-dicarbonitrile (13)

A mixture of compound $4(1710 \mathrm{mg}, 5 \mathrm{mmol})$ and 2,3-dichloroquinoxaline (12) (1000 $\mathrm{mg}, 5 \mathrm{mmol})$ in dry pyridine $(30 \mathrm{~mL})$ was refluxed for $4 \mathrm{~h}$. After cooling, the reaction mixture was poured onto ice-water and neutralized with diluted $\mathrm{HCl}$. The formed solid was filtered and crystallized from $\mathrm{DMF} / \mathrm{H}_{2} \mathrm{O}$ to afford $\mathbf{1 3}$ as pale brown crystals, yield $45 \%, \mathrm{mp}>300{ }^{\circ} \mathrm{C}$. IR $(\mathrm{KBr}) \mathrm{v}_{\max } / \mathrm{cm}^{-1}$ : 3394, (br, NH), $3101(\mathrm{NH}), 3040\left(\mathrm{C}-\mathrm{H}_{\text {arom }}\right), 2241$ $(2 \mathrm{C} \equiv \mathrm{N}), 1675\left(\mathrm{C}=\mathrm{O}_{\text {pyridone }}\right), 1619\left(\mathrm{C}=\mathrm{O}_{\text {pyrone }}\right), 1556(\mathrm{C}=\mathrm{N})$. ${ }^{1} \mathrm{H}$ NMR (DMSO- $d_{6}$ ) $\delta 7.01-8.07$ (m, 6H, Ar-H), 8.68 (s, $1 \mathrm{H}, \mathrm{H}-5), 9.53$ (s, 1H, H-2), 10.72 (br, 1H, $\mathrm{NH}_{\text {triazine }}$ ), 11.28 (br, $1 \mathrm{H}, \mathrm{NH}_{\text {quinaoxaline }}$ ), $11.94\left(\mathrm{br}, 1 \mathrm{H}, \mathrm{NH}_{\text {triazine }}\right), 12.21$ (br, $1 \mathrm{H}, \mathrm{NH}_{\text {quinaoxaline }}$. Anal. Calc. for $\mathrm{C}_{24} \mathrm{H}_{10} \mathrm{ClN}_{7} \mathrm{O}_{3}$ (479.83): C, 60.07; H, 2.10; N, 20.43; Cl, 7.38. Found: C, 59.69; $\mathrm{H}, 1.86 ; \mathrm{N}, 20.07 ; \mathrm{Cl}, 7.02 \%$.

11 -(6-Chloro-4-oxo-4H-chromen-3-yl)-9-oxo-2,3diphenyl-7H-pyrido[1,2-b][1,2,4] triazino[3 $2: 3,4]$ triazino[5,6-e][1,2,4]triazine-10,12-dicarbonitrile (15)

A mixture of compound $4(1710 \mathrm{mg}, 5 \mathrm{mmol})$ and 3-chloro-7,8-diphenyl-4H-[1,2,4]triazino[4,3-b][1,2,4] triazin-4-one $(\mathbf{1 4})(1720 \mathrm{mg}, 5 \mathrm{mmol})$ in dry pyridine $(30 \mathrm{~mL})$ was refluxed for $12 \mathrm{~h}$. After cooling, the reaction mixture was poured onto ice-water, and neutralized with diluted $\mathrm{HCl}$. The formed solid was filtered and crystallized from acetic acid to afford $\mathbf{1 5}$ as brown crystals, yield $49 \%$, mp 225-227 ${ }^{\circ} \mathrm{C}$. IR (KBr) $v_{\max } / \mathrm{cm}^{-1}: 3200$ (br, NH), $3064\left(\mathrm{C}-\mathrm{H}_{\text {arom }}\right), 2224(2 \mathrm{C} \equiv \mathrm{N}), 1675\left(\mathrm{C}=\mathrm{O}_{\text {pyridone }}\right), 1636$ $\left(\mathrm{C}=\mathrm{O}_{\text {pyrone }}\right), 1600(\mathrm{C}=\mathrm{N}) .{ }^{1} \mathrm{H}$ NMR $\left(\mathrm{DMSO}-d_{6}\right) \delta 7.14-8.37$ (m, 12H, Ar-H), 8.52 (s, 1H, H-5), 9.46 (s, 1H, H-2), 10.82 (s, $1 \mathrm{H}, \mathrm{NH})$. Anal. Calc. for $\mathrm{C}_{33} \mathrm{H}_{15} \mathrm{ClN}_{10} \mathrm{O}_{3}$ (634.99): C, 62.42; H, 2.38; N, 22.06; Cl, 5.58. Found: C, 62.16; $\mathrm{H}, 2.07 ; \mathrm{N}, 21.78 ; \mathrm{Cl}, 5.19 \%$.

9-(6-Chloro-4-oxo-4H-chromen-3-yl)-2,4-dimethyl-7oxo-3,7-dihydropyrido[1,2-b][1,2,4] triazepine-8,10dicarbonitrile (17)

A mixture of compound $4(1710 \mathrm{mg}, 5 \mathrm{mmol})$ and acetylacetone $(500 \mathrm{mg}, 5 \mathrm{mmol})$, in DMF ( $30 \mathrm{~mL}$ ) containing few drops of piperidine, was refluxed for $10 \mathrm{~h}$. After cooling, the reaction mixture was poured onto ice-water. The formed solid was filtered and crystallized from ethanol to afford $\mathbf{1 7}$ as brown crystals, yield 59\%, mp 182-184 ${ }^{\circ} \mathrm{C}$. IR (KBr) $v_{\text {max }} / \mathrm{cm}^{-1}: 3042\left(\mathrm{C}-\mathrm{H}_{\text {arom }}\right), 2977\left(\mathrm{C}-\mathrm{H}_{\text {aliph }}\right), 2261,2219$ $(2 \mathrm{C} \equiv \mathrm{N}), 1683\left(\mathrm{C}=\mathrm{O}_{\text {pyridone }}\right), 1637\left(\mathrm{C}=\mathrm{O}_{\text {pyrone }}\right), 1600(\mathrm{C}=\mathrm{N})$. ${ }^{1} \mathrm{H}$ NMR (DMSO- $\left.d_{6}\right) \delta 2.94$ (s, $3 \mathrm{H}, \mathrm{CH}_{3}$ ), $3.16\left(\mathrm{~s}, 3 \mathrm{H}, \mathrm{CH}_{3}\right.$ ), 4.63 (br, 2H, $\mathrm{CH}_{2}$ ), 6.90-7.45 (m, 2H, H-8 and H-7), 8.51 (s, $1 \mathrm{H}, \mathrm{H}-5), 8.96$ (s, 1H, H-2). Anal. Calc for $\mathrm{C}_{21} \mathrm{H}_{12} \mathrm{ClN}_{5} \mathrm{O}_{3}$ (417.80): C, 60.37; H, 2.89; N, 16.76; Cl, 8.48. Found: C, $60.03 ; \mathrm{H}, 2.57 ; \mathrm{N}, 16.43 ; \mathrm{Cl}, 8.19 \%$.

2-Amino-9-(6-chloro-4-oxo-4H-chromen-3-yl)-4-(4chlorophenyl)-7-oxo-dihydro-pyrido [1,2-b][1,2,4] triazepine-3,8,10-tricarbonitrile (18)

A mixture of compound $4(1710 \mathrm{mg}, 5 \mathrm{mmol})$ and (4-chlorobenzylidene) malononitrile (16) $(940 \mathrm{mg}$, $5 \mathrm{mmol}$ ), in DMF (30 mL) containing a few drops of piperidine, was refluxed for $10 \mathrm{~h}$. After cooling, the reaction mixture was poured onto ice-water. The formed solid was filtered and crystallized from DMF to afford $\mathbf{1 8}$ as red crystals, yield $39 \%, \mathrm{mp}>300^{\circ} \mathrm{C}$. IR $(\mathrm{KBr}) v_{\max } / \mathrm{cm}^{-1}: 3276$, $3199\left(\mathrm{NH}_{2}, \mathrm{NH}\right), 3070\left(\mathrm{C}-\mathrm{H}_{\text {arom }}\right), 2276(2 \mathrm{C} \equiv \mathrm{N}), 2216$ $(\mathrm{C} \equiv \mathrm{N}), 1676\left(\mathrm{C}=\mathrm{O}_{\text {pyridone }}\right), 1619\left(\mathrm{C}=\mathrm{O}_{\text {pyrone }}\right), 1592(\mathrm{C}=\mathrm{N})$, $1466\left(\mathrm{NH}_{2}\right.$ def). ${ }^{1} \mathrm{H}$ NMR (DMSO- $\left.d_{6}\right) \delta 7.10-8.19(\mathrm{~m}, 6 \mathrm{H}$, Ar-H), 8.61 (s, 1H, H-5), 8.89 (br, 2H, NH $)_{2}, 9.54$ (s, 1H, $\mathrm{H}-2$ ), 10.67 (br, $1 \mathrm{H}, \mathrm{NH}$ ). Anal. Calc. for $\mathrm{C}_{26} \mathrm{H}_{11} \mathrm{Cl}_{2} \mathrm{~N}_{7} \mathrm{O}_{3}$ (540.31): C, 57.80; H, 2.05; N, 18.15; Cl, 13.12. Found: C, $57.52 ; \mathrm{H}, 1.78 ; \mathrm{N}, 17.77 ; \mathrm{Cl}, 12.94 \%$.

9-(6-Chloro-4-oxo-4H-chromen-3-yl)-2-methyl-7-oxo-5,7dihydropyrido[1,2-b][1,2,4] triazepine-8,10-dicarbonitrile (20)

A mixture of compound $4(1710 \mathrm{mg}, 5 \mathrm{mmol})$ and 4-(dimethylamino)but-3-en-2-one (19) $(570 \mathrm{mg}, 5 \mathrm{mmol})$ in glacial acetic acid $(30 \mathrm{~mL})$ was refluxed for $10 \mathrm{~h}$. After cooling, the reaction mixture was poured onto ice-water. The formed solid was filtered and crystallized from DMF/ ethanol to afford $\mathbf{2 0}$ as pale brown crystals, yield 96\%, mp 200-202 ${ }^{\circ} \mathrm{C}$. IR (KBr) $v_{\max } / \mathrm{cm}^{-1}: 3394(\mathrm{NH}), 3039$ $\left(\mathrm{C}-\mathrm{H}_{\text {arom }}\right), 2925\left(\mathrm{C}-\mathrm{H}_{\text {aliph }}\right), 2260(2 \mathrm{C} \equiv \mathrm{N}), 1683\left(\mathrm{C}=\mathrm{O}_{\text {pyridone }}\right)$, $1625\left(\mathrm{C}=\mathrm{O}_{\text {pyrone }}\right), 1597(\mathrm{C}=\mathrm{N}) .{ }^{1} \mathrm{H}$ NMR $\left(\mathrm{DMSO}-d_{6}\right) \delta 2.34$ (s, 3H, $\left.\mathrm{CH}_{3}\right), 6.91-7.42\left(\mathrm{~m}, 2 \mathrm{H}, \mathrm{H}-8\right.$ and $\left.\mathrm{C}_{6}-\mathrm{H}_{\text {triazepine }}\right), 7.49$ (d, 1H, J $7.8 \mathrm{~Hz}, \mathrm{H}-7), 7.94$ (d, 1H, J $8 \mathrm{~Hz}, \mathrm{C}_{7}-\mathrm{H}_{\text {triazepine }}$ ), 8.52 (s, 1H, H-5), 9.46 (s, 1H, H-2), 10.67 (s, 1H, NH). Anal. Calc. for $\mathrm{C}_{20} \mathrm{H}_{10} \mathrm{ClN}_{5} \mathrm{O}_{3}$ (403.77): C, 59.49; H, 2.50; N, 17.34; Cl, 8.78. Found: C, 59.13; H, 2.37; N, 16.97; $\mathrm{Cl}, 8.43 \%$.

2-Amino-9-(6-chloro-4-oxo-4H-chromen-3-yl)8,10-dicyano- $N$-phenyl-4-(phenylamino)-7-oxo-5,7dihydropyrido[1,2-b][1,2,4]triazepine-3-carboxamide (22)

A mixture of compound $4(1710 \mathrm{mg}, 5 \mathrm{mmol})$ and 2-cyano-3-(methylsulfanyl)- $N$-phenyl-3-(phenylamino) 
prop-2-enamide (21) (1550 mg, $5 \mathrm{mmol}$ ), in DMF (30 mL) containing few drops of piperidine, was refluxed for $10 \mathrm{~h}$. After cooling, the reaction mixture was poured onto icewater. The formed solid was filtered and crystallized from DMF/ethanol to afford $\mathbf{2 2}$ as pale brown crystals, yield $61 \%$, mp 263-265 ${ }^{\circ} \mathrm{C}$. IR (KBr) $v_{\max } / \mathrm{cm}^{-1}: 3375,3325$, $3152\left(\mathrm{NH}_{2}, 3 \mathrm{NH}\right), 3071\left(\mathrm{C}-\mathrm{H}_{\text {arom }}\right), 2221(2 \mathrm{C} \equiv \mathrm{N}), 1669$ $\left(\mathrm{C}=\mathrm{O}_{\text {pyridone }}\right), 1648\left(\mathrm{C}=\mathrm{O}_{\text {amide }}\right), 1630\left(\mathrm{C}=\mathrm{O}_{\text {pyrone }}\right), 1600$ $(\mathrm{C}=\mathrm{N}) .{ }^{~} \mathrm{H}$ NMR $\left(\mathrm{DMSO}-d_{6}\right) \delta 6.94-7.68(\mathrm{~m}, 12 \mathrm{H}, \mathrm{Ar}-\mathrm{H})$, $8.08\left(\mathrm{br}, 2 \mathrm{H}, \mathrm{NH}_{2}\right), 8.66$ (s, 1H, H-5), 9.21 (s, 1H, H-2), 9.91 (s, 1H, NH), 10.63 (s, 1H, NH), 11.08 (br, 1H, NH). Anal. Calc. for $\mathrm{C}_{32} \mathrm{H}_{19} \mathrm{ClN}_{8} \mathrm{O}_{4}$ (614.99): C, 62.49; H, 3.11; $\mathrm{N}, 18.22 ; \mathrm{Cl}, 5.76$. Found: C, 62.09; H, 2.78; N, 17.81; $\mathrm{Cl}, 5.43 \%$.

\section{Supplementary Information}

Supplementary data are available free of charge at http://jbcs.sbq.org.br, as pdf file.

\section{References}

1. Djerngou, P. C.; Gatsing, D.; Tehuendem, M.; Ngadjui, B. T.; Tane, P.; Ahmed, A. A.; Gamal-Eldeen, A. M.; Adoga, G. I.; Hirata, T.; Mabry, T.; J. Nat. Prod. Commun. 2006, 1, 961.

2. Peng, J. Y.; Dong, F. Q.; Liu, K. X.; Xu, Y. W.; Qi, Y.; Xu, Q. W.; Xu, L. N.; J. Asian Nat. Prod. Res. 2008, 10, 169.

3. Shi, Y. Q.; Fukai, T.; Sakagami, H.; Chang, W.-J.; Yang, P.-Q.; Wang, F.-P.; Nomura, T.; J. Nat. Prod. 2001, 64, 181.

4. Sharma, V. P.; Asian J. Chem. 2004, 16, 1966. (CA 142: 298061); Sharma, V. P.; Indian J. Heterocycl. Chem. 2004, 14, 35. (CA 142: 373785).

5. Ghate, M.; Kusanur, R. A.; Kulkarni, M. V.; Eur. J. Med. Chem. 2005, 40, 882 .

6. Nandgaonkar, R. G.; Ingle, V. N.; Asian J. Chem. 2005, 17, 2016. (CA 144: 311814); Joshi, N. S.; Shaikh, A. A.; Deshpande, A. P.; Karale, B. K.; Bhirud, S. B.; Gill, C. H.; Indian J. Chem. 2005, 44B, 422.(CA 144: 192164).

7. Siddiqui, Z. N.; Khuwaja, G.; Asad, M.; Heterocycl. Commun. 2006, 12, 443; Ali, T. E.; Abdel-Aziz, S. A.; El-Shaaer, H. M.; Hanafy, F. I.; El-Fauomy, A. Z.; Phosphorus, Sulfur Silicon Relat. Elem. 2008, 183, 2139; Ibrahim M. A.; El-Mahdy K. M.; Phosphorus, Sulfur Silicon Relat. Elem. 2009, 184, 2945.

8. Ali, T. E.; Phosphorus, Sulfur Silicon Relat. Elem. 2007, 182, 1717; Ali, T. E.; Abdel-Aziz, S. A.; El-Shaaer, H. M.; Hanafy F. I.; El-Fauomy, A. Z.; Turk. J. Chem. 2008, 32, 365; Ali, T. E.; Halacheva, S. S.; Heteroat. Chem. 2009, 20, 117.

9. Nawrot-Modranka, J.; Nawrot, E.; Graczyk, J.; Eur. J. Med. Chem. 2006, 41, 1301.

10. Ishar, M. P. S.; Singh, G.; Singh, S.; Sreenivasan, K. K.; Singh, G.; Bioorg. Med. Chem. Lett. 2006, 16, 1366; Barath, Z.; Radics,
R.; Spengler, G.; Ocsovszki, I.; Kawase, M.; Motohashi, N.; Shirataki, Y.; Shah, A.; Molnar, J.; In Vivo 2006, 20, 645; (CA 2007, 146: 287872); Boumendjel, A.; Nicolle, E.; Moraux, T.; Gerby, B.; Blanc, M.; Ronot, X.; Boutonnat, J.; J. Med. Chem. 2005, 48, 7275.

11. Collins, I.; Castro, J. L.; Tetrahedron Lett. 1999, 40, 4069; Aberg, V.; Sellstedt, M.; Hedenstrom, M.; Pinkner, J. S.; Hultgren, S. J.; Almqvist, F.; Bioorg. Med. Chem. 2006, 14, 7563.

12. Ozturk, G.; Erol, D. D.; Aytemir, M. D.; Uzbay, T.; Eur. J. Med. Chem. 2002, 37, 829.

13. Amr, A. E.; Abdulla, M. M.; Bioorg. Med. Chem. 2006, 14, 4341.

14. Amr, A. E.; Mohamed, A. M.; Mohamed, S. F.; Abdel-Hafez, N. A.; Hammam, A. E.; Bioorg. Med. Chem. 2006, 14, 5481; Du, W. Tetrahedron 2003, 59, 8649; Cocco, M. T.; Congiu, C.; Onnis V.; Eur. J. Med. Chem. 2000, 35, 545.

15. Ünver, Y.; Düğdü, E.; Sancak, K.; Er, M.; Karaoğlu, Ş.; Turk. J. Chem. 2008, 32, 441; Özdemir, A.; Turan-Zitouni, G.; Kaplancikli, Z. A.; Chevallet, P.; J. Enzyme Inhib. Med. Chem. 2007, 22, 511.

16. Vivet-Boudou, V.; Paillart, J. C.; Burger, A.; Marquet, R.; Nucleosides, Nucleotides Nucleic Acids 2007, 26, 743; Kiselyov, A. S.; Piatnitski, E.; Milligan, D.; Ouyang, X.; Chem. Biol. Drug Des. 2007, 69, 331.

17. Kumar, J.; Prabhakaran, J.; Majo, V.; Milak, M.; Hsiung, S. C.; Tamir, H.; Simpson, N.; Heertum, R.; Mann, J.; Parsey, R.; Eur. J. Nucl. Med. Mol. Imaging 2007, 34, 1050; El-Mariah, F; Hosny, M; Deeb, A.; Phosphorus, Sulfur Silicon Relat. Elem. 2006, 181, 2505.

18. Mansour, A.; Eid, M. M.; Khalil, N. S. A. M.; Nucleosides, Nucleotides Nucleic Acids 2003, 22, 1805; Mansour, A.; Eid, M. M.; Khalil, N. S. A. M.; Nucleosides, Nucleotides Nucleic Acids 2003, 22, 21.

19. Reayi, A.; Hosmane, R. S.; J. Med. Chem. 2004, 47, 1044; Reayi, A.; Hosmane, R. S.; Nucleosides, Nucleotides Nucleic Acids 2004, 23, 263.

20. Ali, T. E.; Eur. J. Med. Chem. 2009, 44, 4385; Lamsabhi, M.; Esseffar, M.; Bouab, W.; El Messaoudi, T.; El Messaoudi, M.; Abboud, J. L. M.; Acami, M.; Yanez, M.; J. Phys. Chem. A 2002, 106, 7383.

21. Al-Najjar, A. A.; Amer, S. A.; Raid, M.; Elghamry, I.; Elnagdi, M. H.; J. Chem. Res. 1996, 296.

22. Ibrahim, M. A.; Abdel-Rahman, R. M.; Abdel-Halim, A. M.; Ibrahim, S. S.; Allimony, H. A.; Arkivoc 2008, 202; Ibrahim, M. A.; Abdel-Rahman, R. M.; Abdel-Halim, A. M.; Ibrahim, S. S.; Allimony, H. A.; J. Braz. Chem. Soc. 2009, 20, 1275.

23. Ali, T. E.; Abdel-Monem, W. R.; Phosphorus, Sulfur Silicon Relat. Elem. 2008, 183, 2161.

24. Ibrahim, N. S.; Chem. Ind. 1989, 654. 
25. Rahman, A. U.; Choudhary, M. I.; Thomsen, W. J.; Bioassay Techniques for Drug Development, Harwood Academic Publishers: The Netherlands, 2001.

26. Khan, K. M.; Saify, Z. S.; Zeesha, A. K.; Ahmed, M.; Saeed, M; Schick, M.; Kohlbau, H. J.; Voelter, W.; Arzneim. Forsch. 2000, 50, 915.

27. Tuskaev, V. A.; Oganesyan, E. T.; Mutsueva, S. K.; Pharma. Chem. J. 2002, 36, 309.

28. Abdel-Rahman, R. M.; Pharmazie 2001, 56, 18; El-Gendy, Z.; Morsy, J. M.; Allimony, H. A.; Abdel-Monem, W. R.; AbdelRahman, R. M.; Pharmazie 2001, 56, 376.

29. Nohara, A.; Umetani, T.; Sann, O. Y.; Tetrahedron 1974, 30, 3553.
30. Hangarge, R. V.; Sonwane, S. A., Jarikote, D. V.; Shingare, M. S.; Green Chem. 2001, 3, 310.

31. El-Shaaer, H. M.; Foltínová, P.; Lácová, M.; Chovancová, J.; Stankovičová, H.; Il Farmaco 1998, 53, 224.

32. Machida, Y.; Nomoto, S.; Negi, S.; Jkuta, H.; Saito, I.; Synth. Commun. 1980, 10, 889.

33. Abdel-Rahman, R. M.; Seada, M.; Fawzy, M.; El-Baz, I.; Asian J. Chem. 1993, 5, 176.

34. Kurz, T.; Widyan, K.; Elgemeie, G. H.; Phosphorus, Sulfur Silicon Relat. Elem. 2006, 181, 299.

Received: March 24, 2009 Web Release Date: March 4, 2010 
Synthesis and Antimicrobial Activity of Chromone-linked 2-Pyridone Fused with 1,2,4-Triazoles, 1,2,4-Triazines and 1,2,4-Triazepines Ring Systems

Tarik El-Sayed Ali and Magdy Ahmed Ibrahim*

Department of Chemistry, Faculty of Education, Ain Shams University, Roxy 11711, Cairo, Egypt

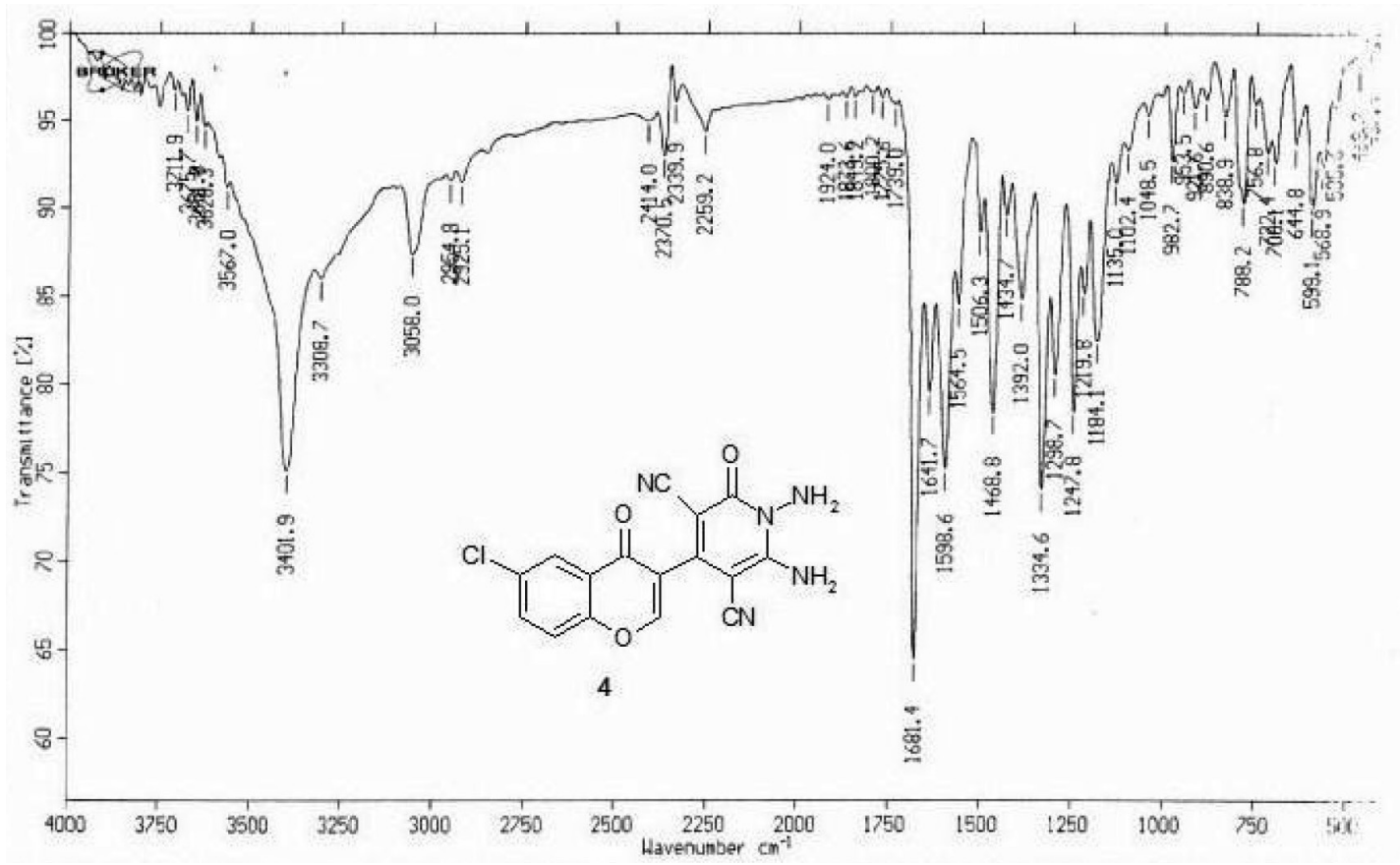

Figure S1. IR spectrum of compound 4. 


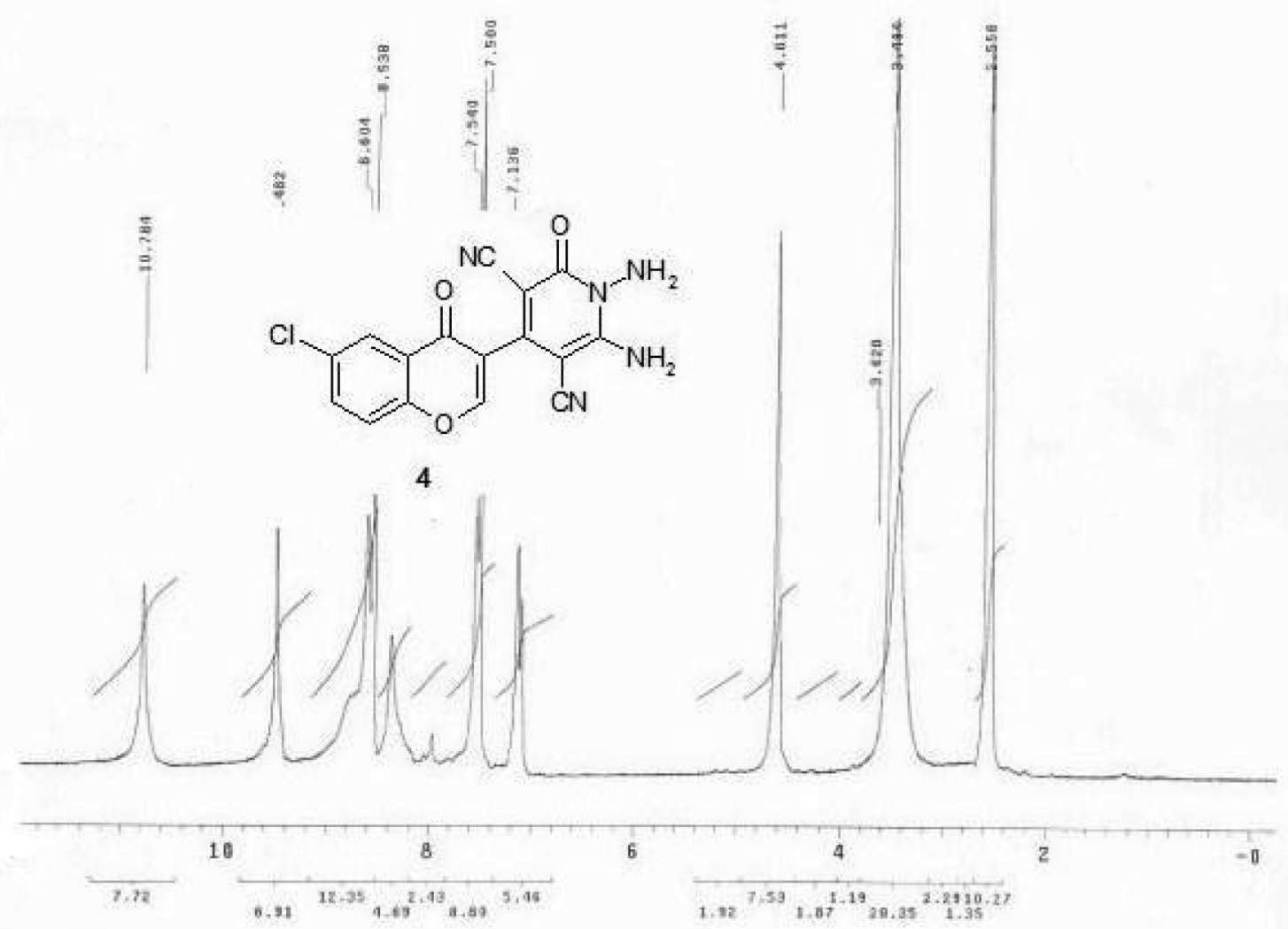

Figure S2. ${ }^{1} \mathrm{H}$ NMR spectrum of compound 4.

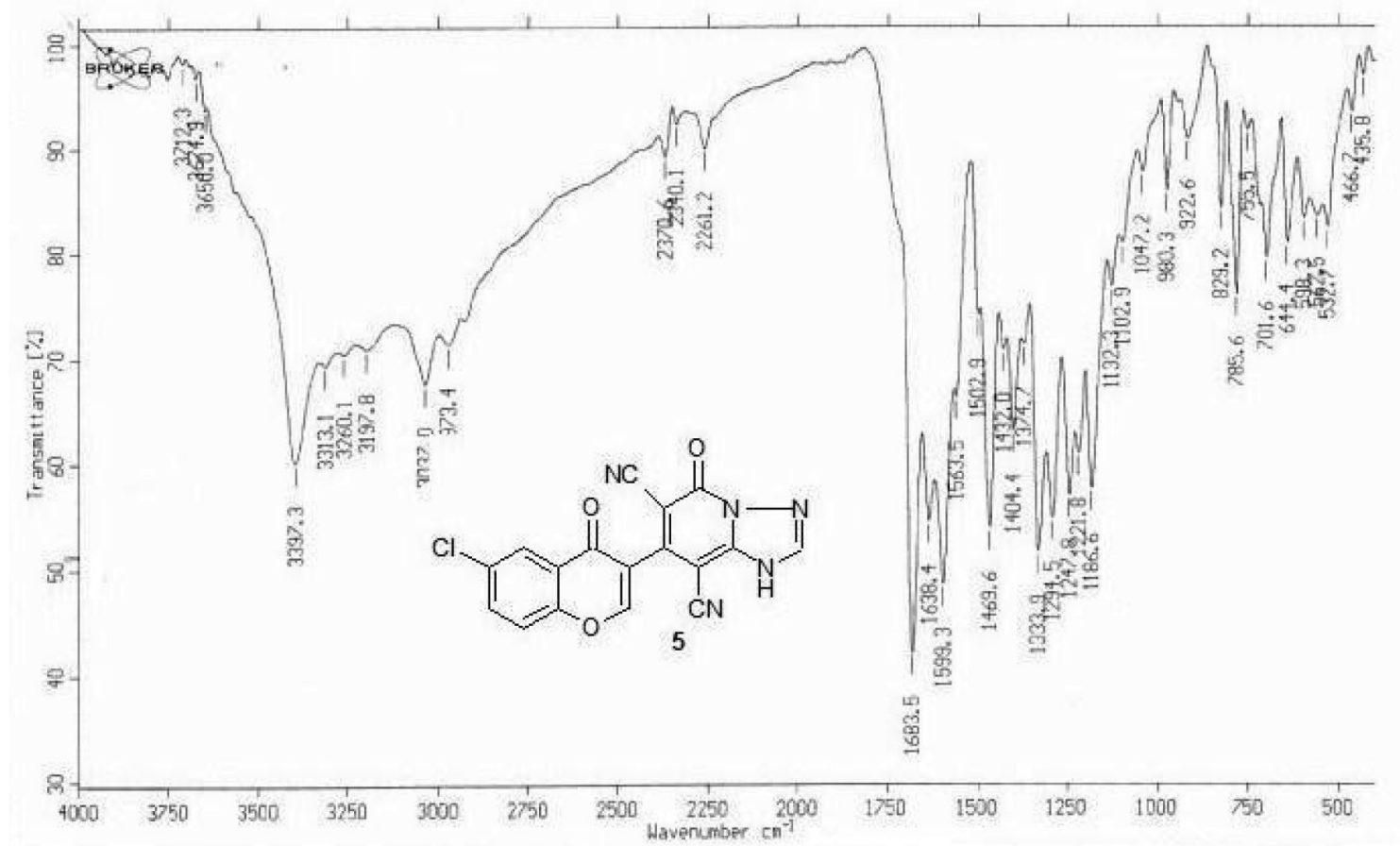

Figure S3. IR spectrum of compound 5 . 


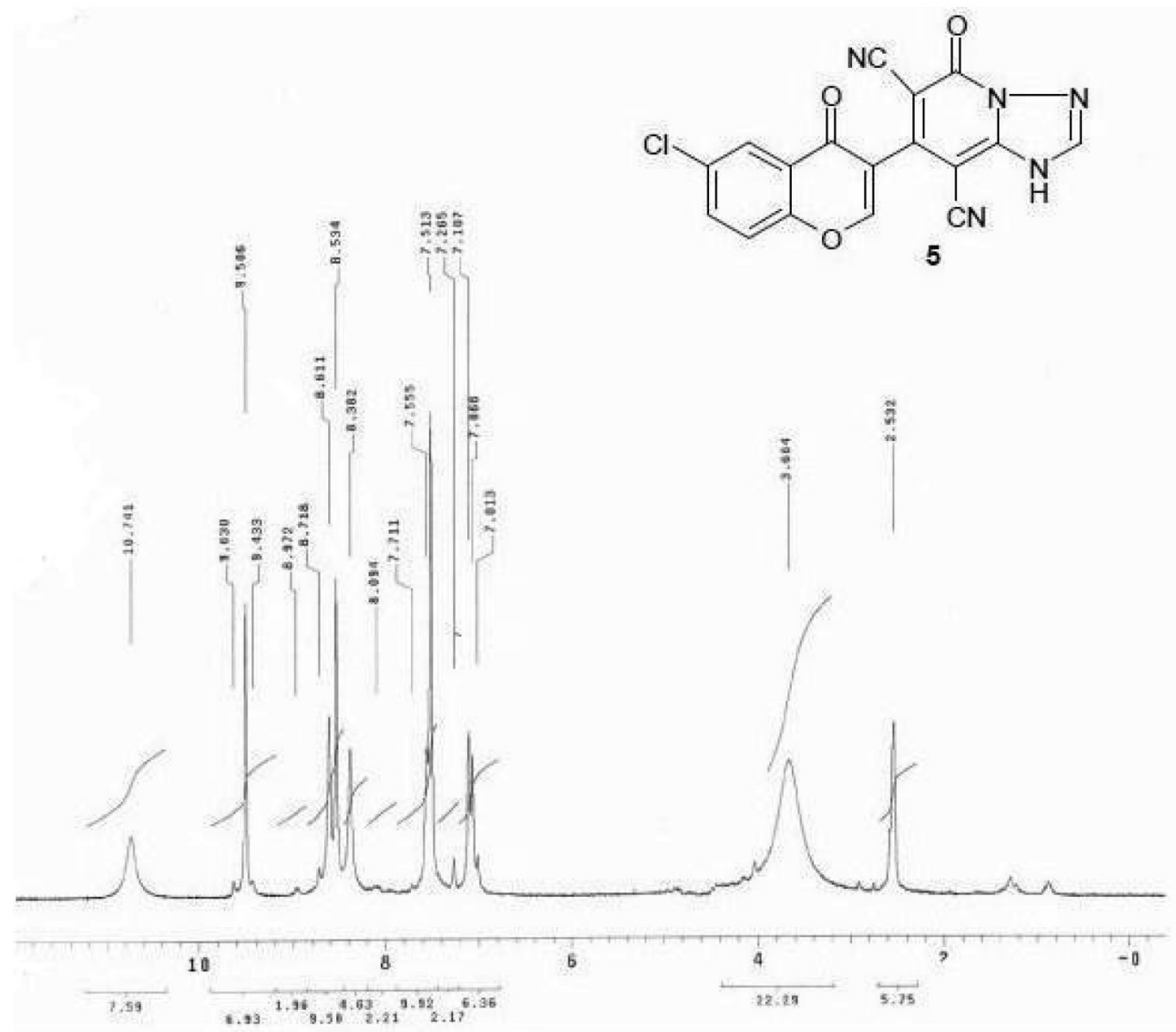

Figure S4. ${ }^{1} \mathrm{H}$ NMR spectrum of compound 5.

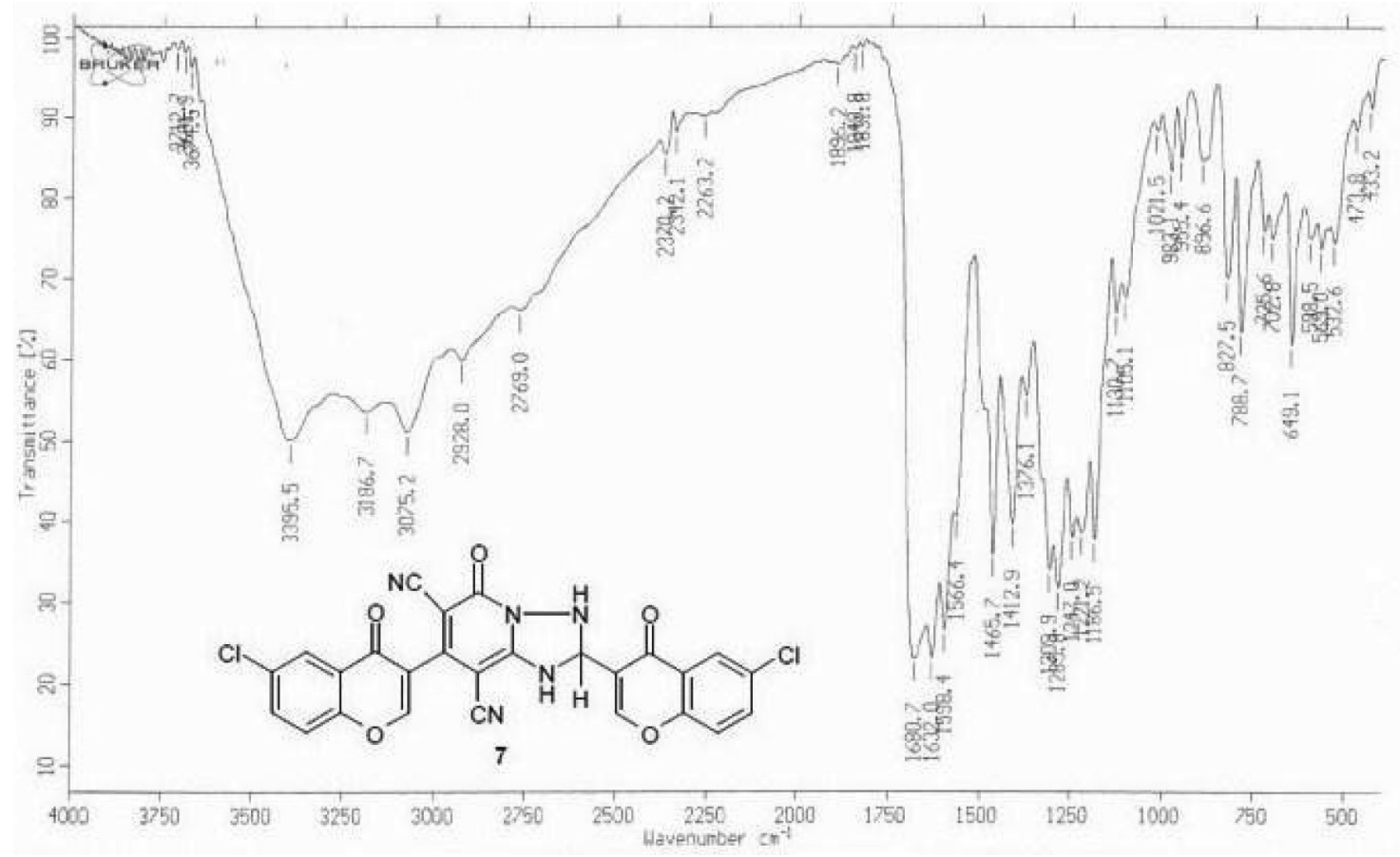

Figure S5. IR spectrum of compound 7. 
<smiles>Cc1c(-c2coc3ccc(Cl)cc3c2=O)c(C#N)c2n(c1=O)N1NC1(c1coc3ccc(Cl)cc3c1=O)N2</smiles>

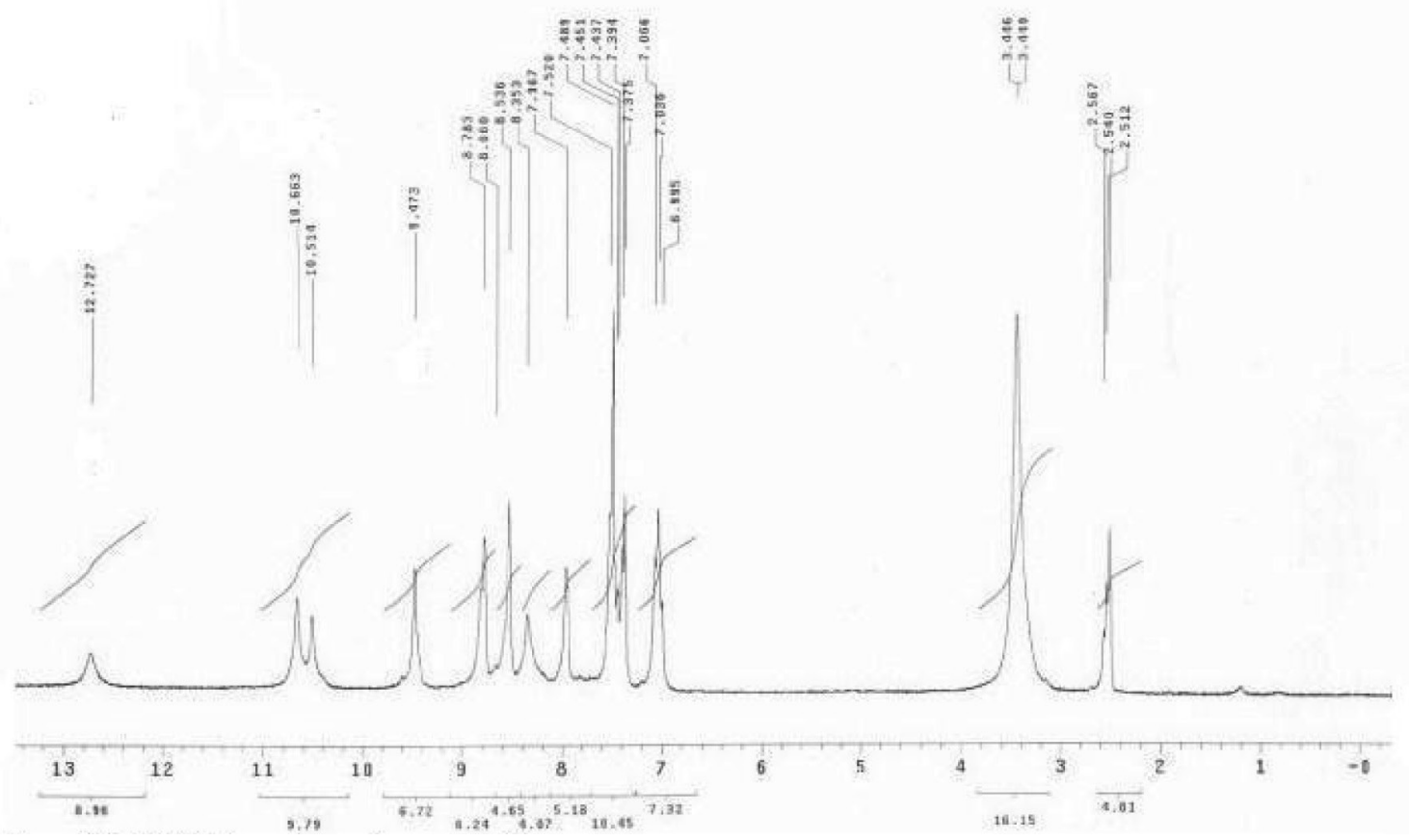

Figure S6. ${ }^{1} \mathrm{H}$ NMRR spectrum of compound 7.

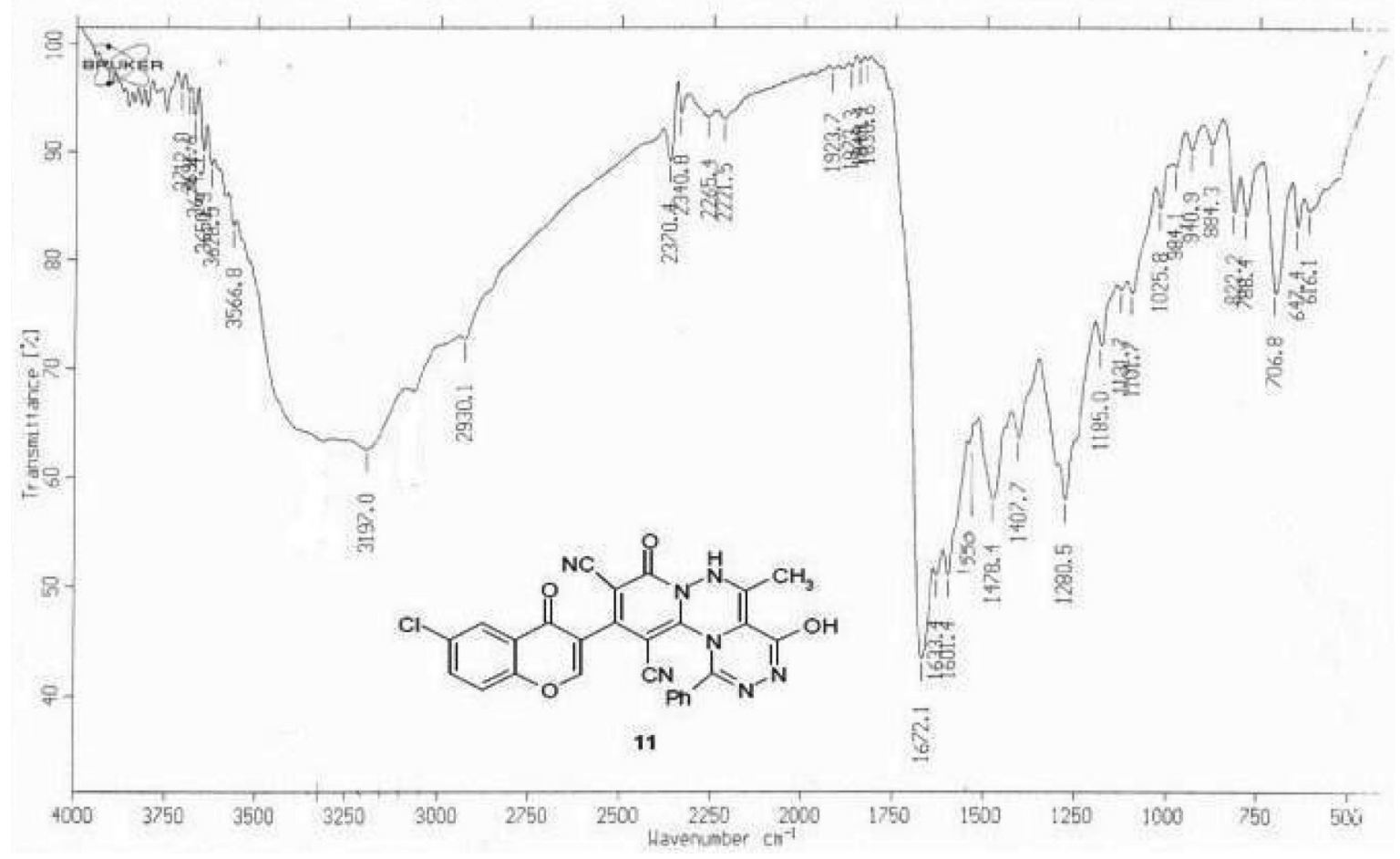

Figure S7. IR spectrum of compound 11. 


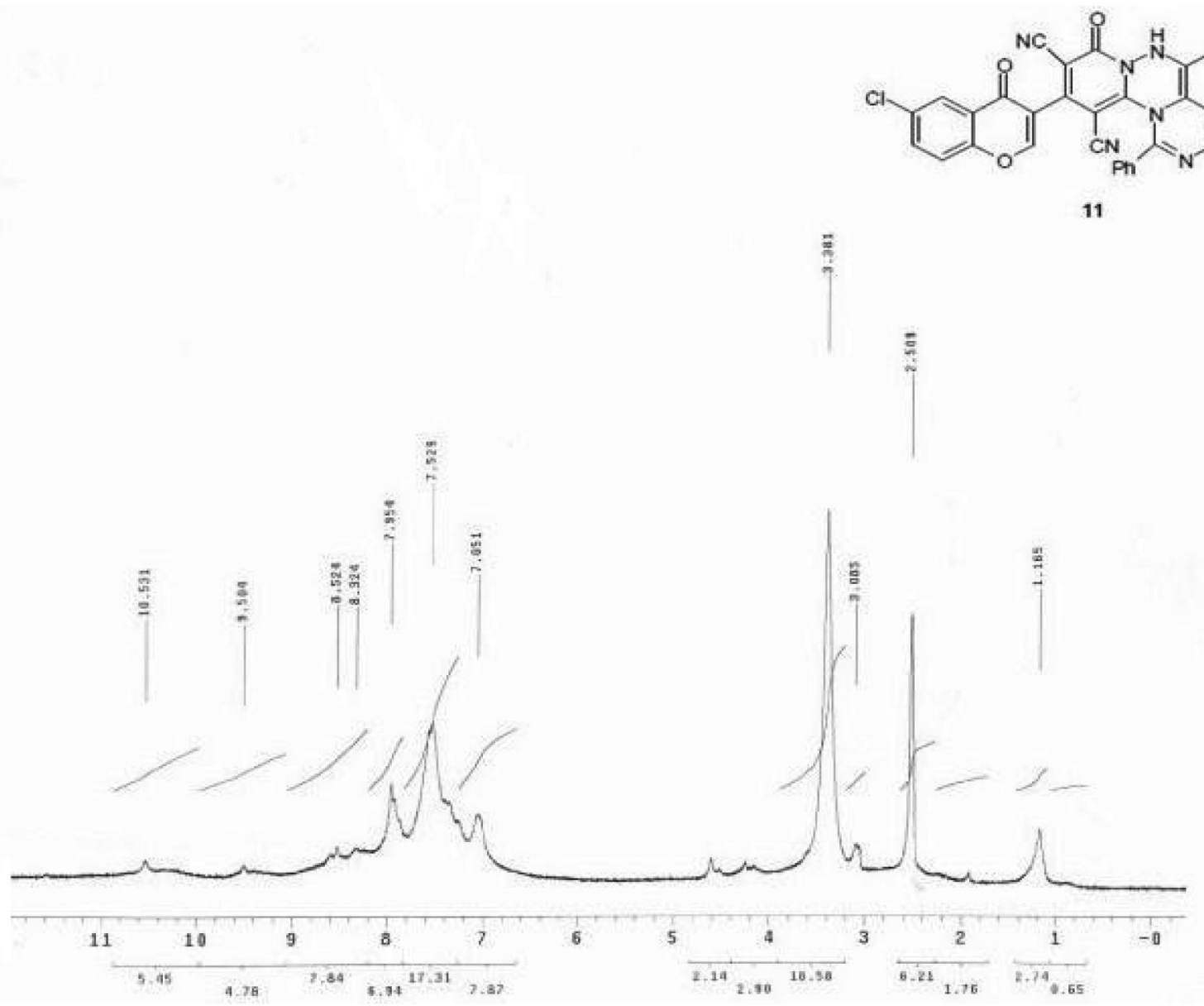

Figure S8. ${ }^{1} \mathrm{H}$ NMR spectrum of compound 11.

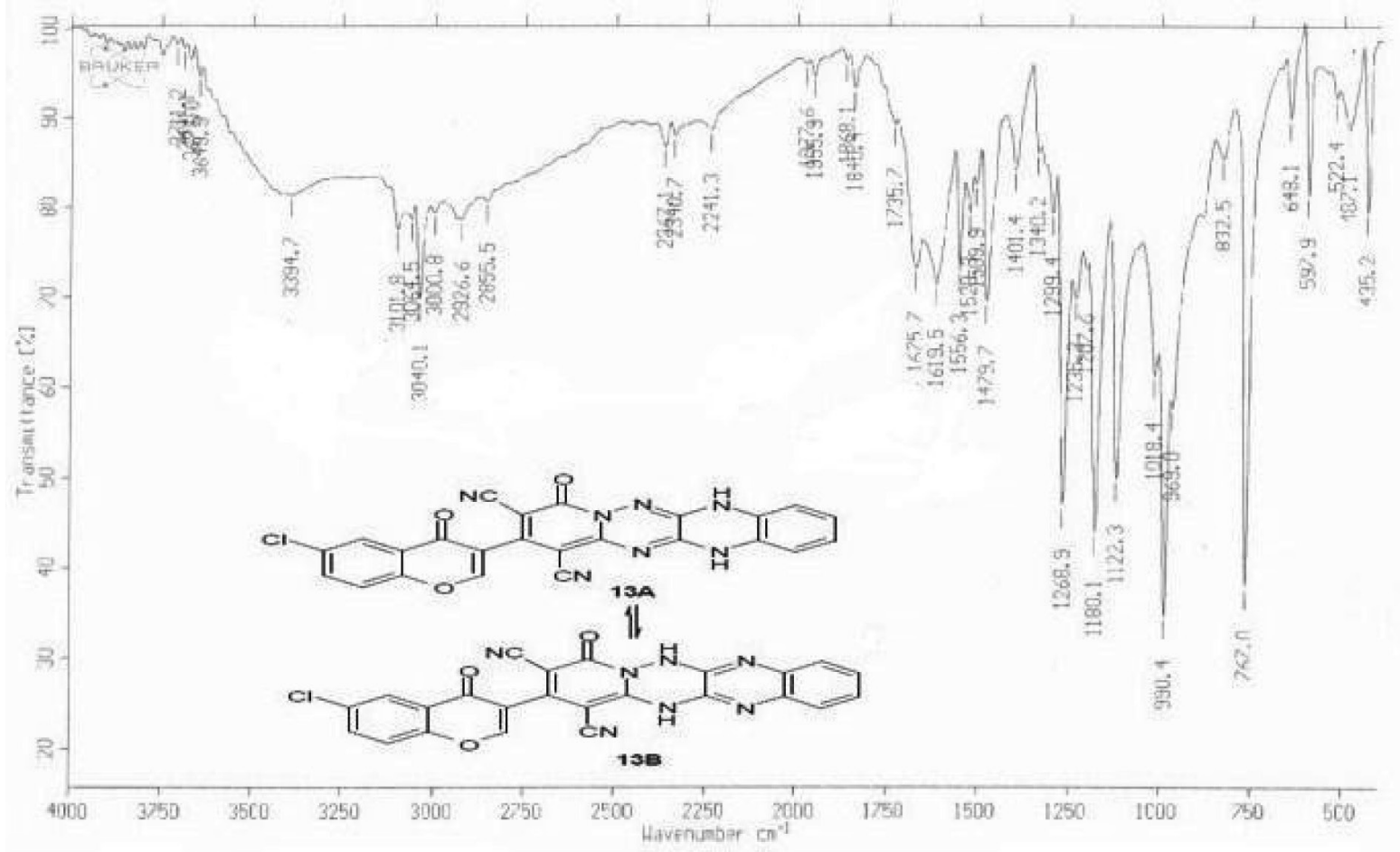

Figure S9. IR spectrum of compound $\mathbf{1 3 .}$ 


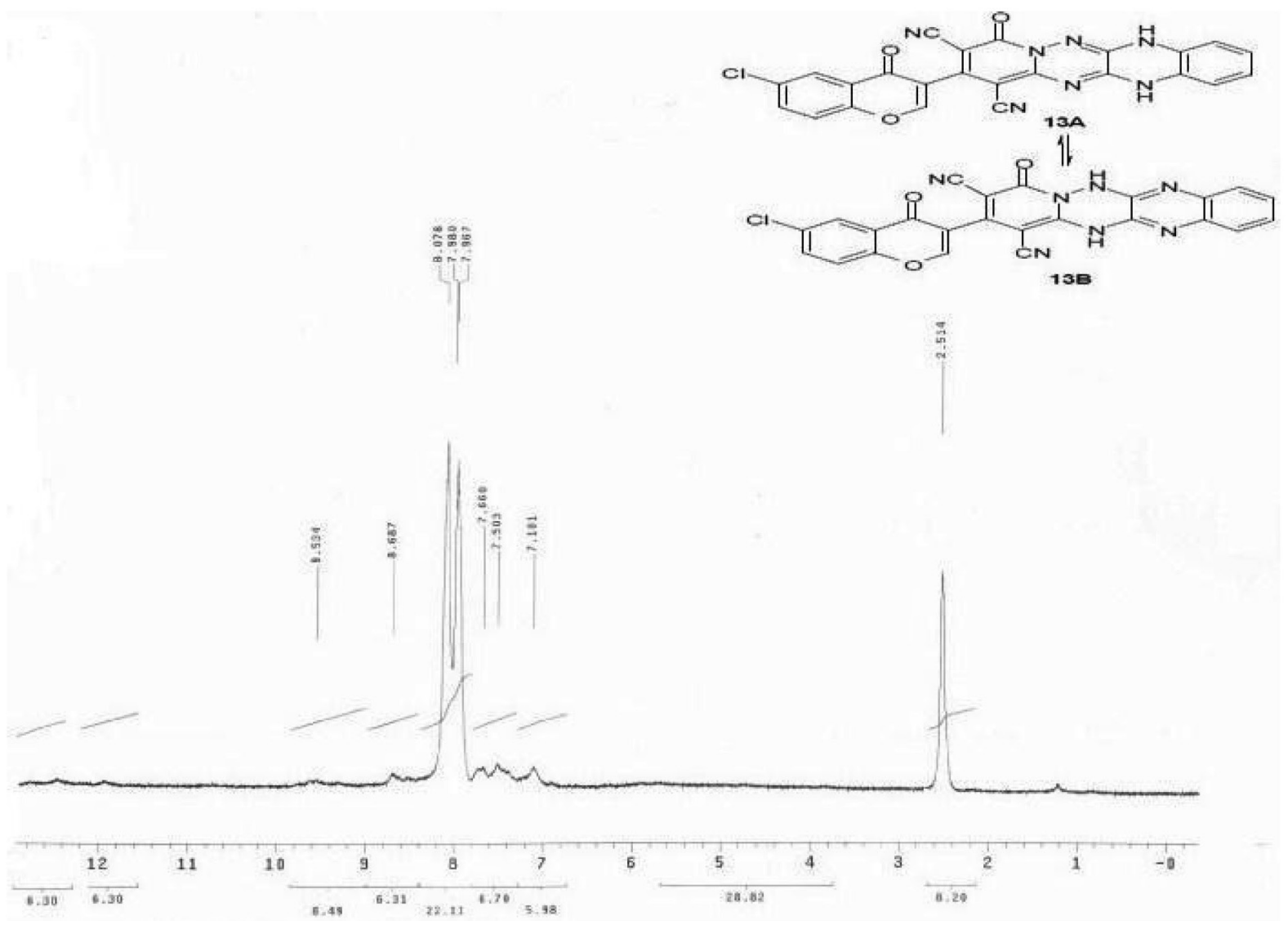

Figure S10. ${ }^{1} \mathrm{H}$ NMR spectrum of compound $\mathbf{1 3}$.

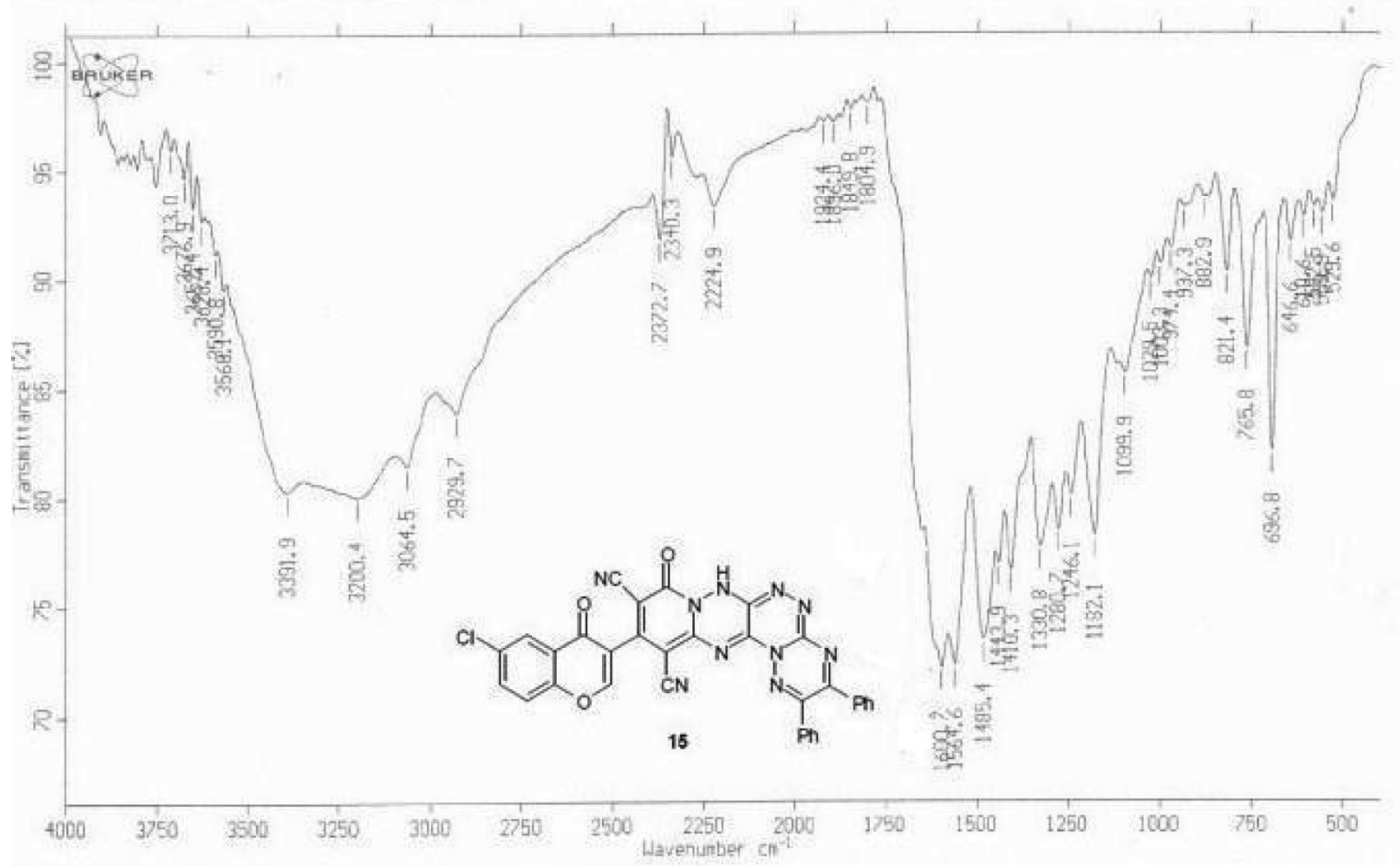

Figure S11. IR spectrum of compound $\mathbf{1 5}$. 


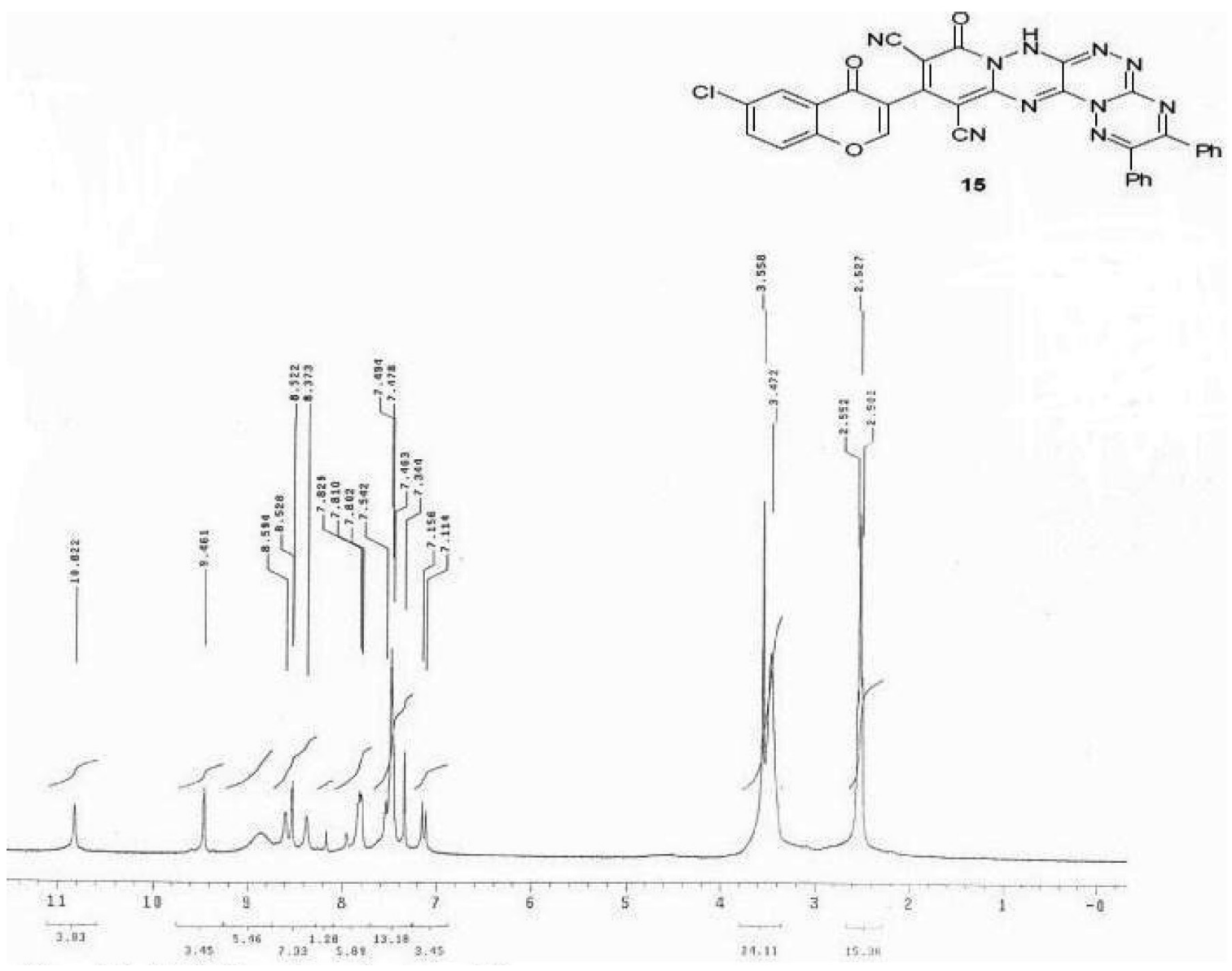

Figure S12. ${ }^{1} \mathrm{H}$ NMR spectrum of compound $\mathbf{1 5}$.

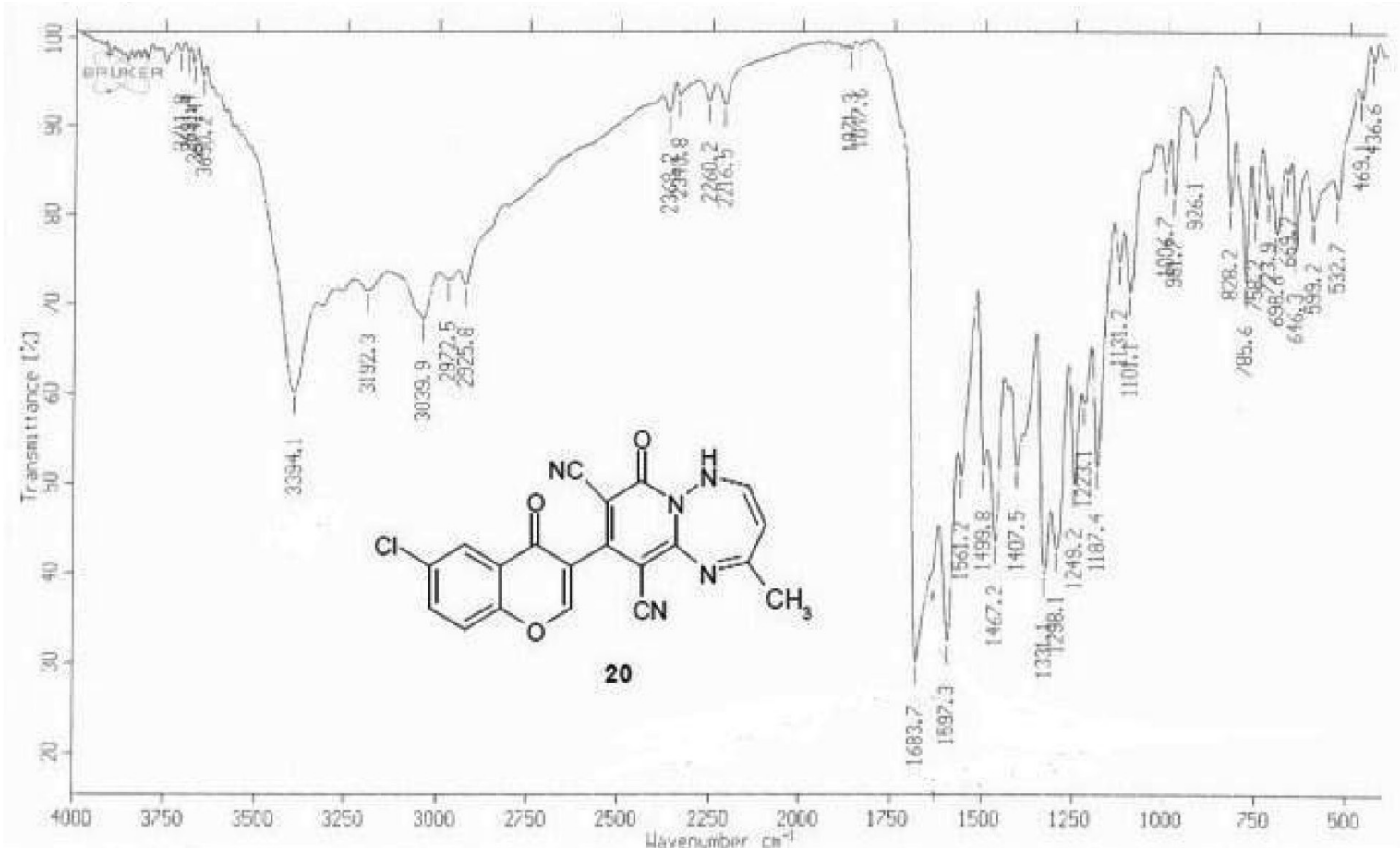

Figure S13. IR spectrum of compound 20. 
SB

Synthesis and Antimicrobial Activity of Chromone-linked 2-Pyridone Fused

J. Braz. Chem. Soc.

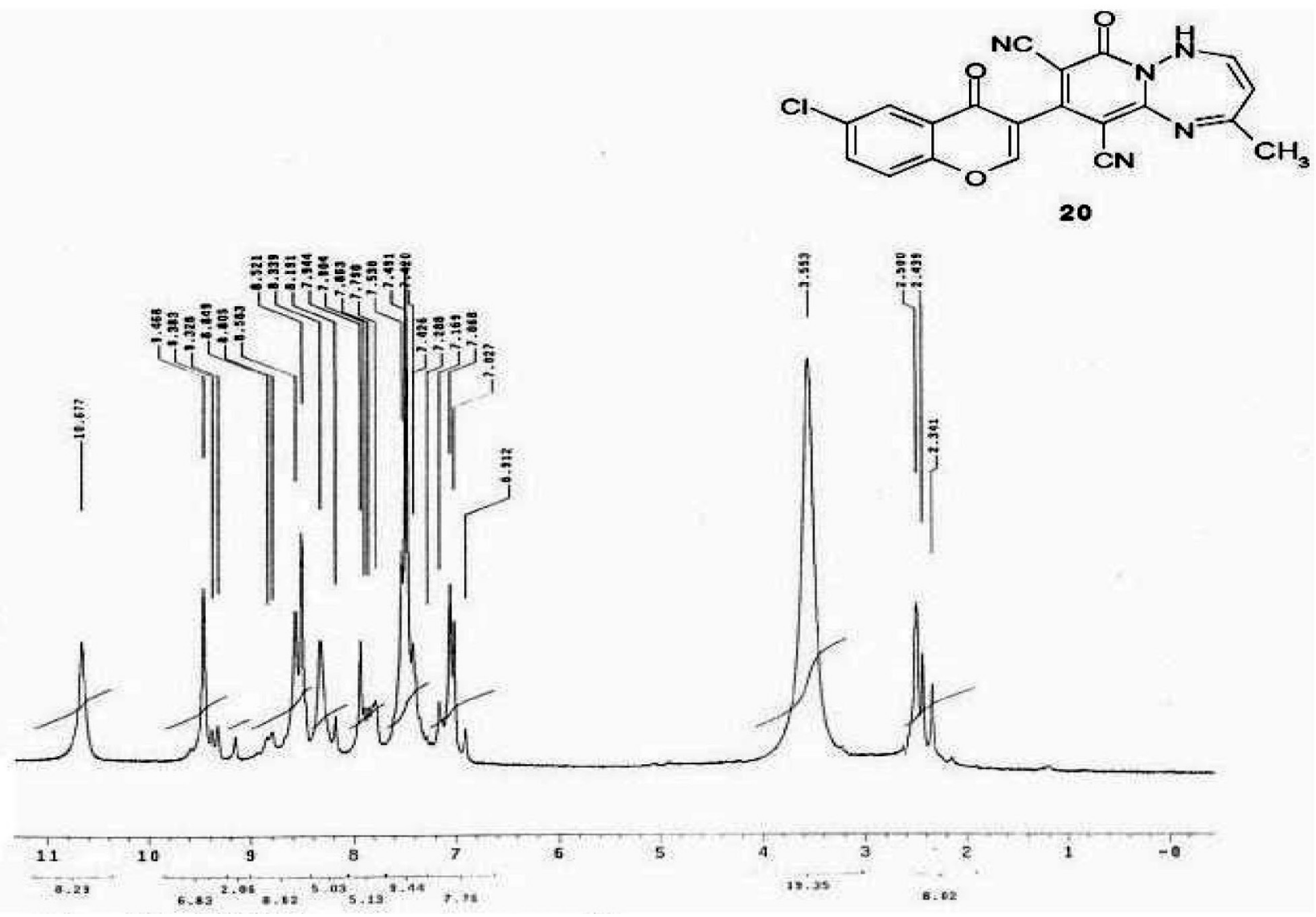

Figure S14. ${ }^{1} \mathrm{H}$ NMR spectrum of compound $\mathbf{2 0 .}$ 